\title{
Molekularne mechanizmy działania genisteiny w świetle terapii chorób genetycznych i immunologicznych
}

\section{Karolina Pierzynowska}

\section{Magdalena Podlacha}

\section{Joanna Brokowska}

\section{Lidia Gaffke}

\section{Jagoda Mantej}

\section{Zuzanna Cyske}

\section{Estera Rintz}

\section{Marta Osiadły}

\section{Michał Bartkowski}

\section{Michał Puchalski}

\section{Michał Grabski}

\section{Michał Pierzynowski}

\section{Dominika Pankanin}

\section{Ewa Piotrowska}

\section{Stefan Tukaj}

\section{Grzegorz Węgrzyn}

Katedra Biologii Molekularnej, Wydział Biologii, Uniwersytet Gdański, Gdańsk

Katedra Biologii Molekularnej, Wydział Biologii, Uniwersytet Gdański, ul. Wita Stwosza 59, 80-308 Gdańsk; tel.: (58) 52360 24; e-mail: grzegorz.wegrzyn@biol.ug.edu.pl

Artykuł otrzymano 21 maja 2018 r. Artykuł zaakceptowano 7 czerwca 2018 r.

Słowa kluczowe: genisteina, choroby rzadkie, choroby genetyczne, choroby immunologiczne

Wykaz skrótów: AD (ang. Alzheimer's disease) choroba Alzheimera; ALS (ang. amyotrophic la teral sclerosis) - stwardnienie zanikowe boczne; ApoE - apolipoproteina; $\beta \mathrm{A}$ - beta-amyloid, powstaje na skutek cięcia prekursora $\beta$ A (APP, ang. amyloid precursor protein); CF (ang. Cystic fibrosis) - mukowiscydoza; CFTR (ang. Cystic Fibrosis Transmembrane Conductance Regulator) błonowy kanał jonowy związany z patogenezą mukowiscydozy; CLEAR (ang. Coordinated Lysosomal Expression and Regulation) - sekwencja

\section{STRESZCZENIE}

Choroby genetyczne i immunologiczne mimo wielu podejmowanych prób leczenia ciągle stanowią duże wyzwanie dla współczesnej medycyny. Obecne formy terapii tych chorób obejmują farmakologiczne łagodzenie ich objawów, rehabilitację czy pomoc psychologiczną, które choć bardzo ważne, nie są niestety wystarczające. Dlatego poszukiwanie nowych terapeutyków, które mogłyby z powodzeniem usuwać główne przyczyny tych chorób, ma ogromne znaczenie dla społeczeństwa. Związki pochodzenia naturalnego wykazują bardzo wiele aktywności biologicznych, dzięki którym są one kandydatami na leki w takich chorobach. Jednym z nich jest genisteina należąca do grupy flawonoidów. Dzięki szeregowi procesów na które wpływa, genisteina znalazła się w centrum zainteresowania naukowców pracujących nad chorobami o różnej etiologii, przebiegu i sposobie dziedziczenia. Wykorzystana została już w eksperymentalnej terapii chorób genetycznych (choroby Huntingtona, stwardnienia zanikowego bocznego, choroby Parkinsona, mukowiscydozy) lub autoimmunizacyjnych i alergicznych. W trakcie przebiegu są próby kliniczne z zastosowaniem genisteiny w chorobie Alzheimera oraz mukopolisacharydozy typu III (w tym drugim przypadku odbywa się próba kliniczna trzeciej fazy). Niezwykle interesującym faktem jest wykorzystanie bardzo zróżnicowanych właściwości genisteiny w próbach leczenia każdej z tych chorób. W niniejszej pracy zebrane zostały informacje o dokładnych molekularnych mechanizmach działania genisteiny $\mathrm{w}$ aspekcie terapii wymienionych wyżej chorób genetycznych oraz immunologicznych wraz $\mathrm{z}$ określeniem terapeutycznego potencjału każdej z aktywności opisywanego flawonoidu, efektywności jego działania oraz potencjalnego wdrożenia leczenia w przyszłości.

\section{WPROWADZENIE}

Choroby genetyczne i immunologiczne stanowią poważny problem dla współczesnego społeczeństwa. W przypadku chorób genetycznych uszkodzeniu ulega materiał genetyczny znajdujący się w każdej komórce organizmu. Dotarcie do wszystkich komórek w celu naprawy błędu jest na obecną chwilę niemożliwe, mimo bardzo szybkiego rozwoju terapii genowej [1] lub kontrowersyjne ze względów etycznych np. w przypadku użycia metody CRISPR/Cas9 [2].

Opracowywane na tę chwilę strategie terapeutyczne są więc indywidualne dla każdej z chorób genetycznych, wykorzystujące charakterystyczne cechy tych schorzeń. Obecne leczenie polega w dużej mierze na farmakologicznym łagodzeniu objawów choroby, rehabilitacji lub pomocy psychologicznej. Natomiast terapie chorób autoimmunologicznych, polegających na atakowaniu własnych komórek przez układ immunologiczny, są problematyczne ze względu na zróżnicowaną przyczynę tych chorób (czynniki genetyczne takie jak predyspozycja do ich występowania, czynniki środowiskowe, zaburzenia hormonal-

regulująca ekspresję genów kodujących białka lizosomalne; EGFR (ang. epidermal growth factor receptor) - receptor naskórkowego czynnika wzrostu; ER (ang. estrogen receptor) - receptor estrogenu; ERT (ang. enzyme replacement therapy) - enzymatyczna terapia zastępcza; GAG - glikozoaminoglikany; ERQC (ang. Protein Folding and Quality Control) - system kontroli jakości białek; fAD (ang. familial AD) - postać rodzinna AD; fALS (ang. familial ALS) - rodzinna ALS; GPER (ang. G protein-coupled estrogen receptor 1 ) - receptor estrogenu sprzężony z białkiem G; HD (ang. Huntington's disease) - choroba Huntingtona; HTT - huntingtyna; mHTT - zmutowana huntingtyna; MDA - aldehyd dimalonowy; MPS (ang. mucopolisaccharidosis) - mukopolisacharydozy; MSD (ang. membrane-spanning domain) - domeny transbłonowe; mTOR (ang. mammalian Target of Rapamycin) - kinazy mTOR; NBD (ang. nucleotide binding domain) - domeny wiążące nukleotydy; 3-NPA - kwas 3-nitropropionowym; 6-OHDA - 6-hydroksydopamina; PD (ang. Parkinson's disease) - choroba Parkinsona; ROS (ang. reactive oxigen species) - reaktywne formy tlenu; SOD1 (ang. copper-zinc superoxide dismutase) - cynkowo-miedziowa dysmutaza ponadtlenkowa (CuZnSOD); SRT (ang. substrate reduction therapy) - redukcja syntezy substratu; TFEB (ang. transcription factor EB) - czynnik transkrypcyjnego EB

Podziekowania: Praca autorów jest finansowana przez Narodowe Centrum Nauki w ramach projektów nr: 2017/25/B/NZ6/00305, 2017/25/B/NZ2/00414 oraz 2017/25/N/NZ2/00812. 


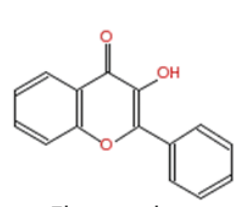

Flawonole

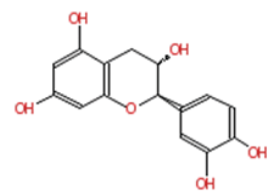

Flawanole (katechiny)<smiles>O=c1cc(-c2ccccc2)oc2ccccc12</smiles>

Flawony<smiles>O=c1c(-c2ccccc2)coc2ccccc12</smiles>

Izoflawony

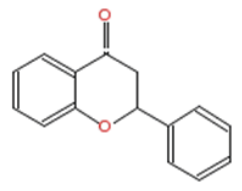

Flawanony

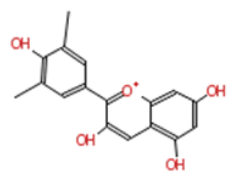

Antocyjanidyny
Rycina 1. Główne grupy flawonoidów.

ne czy infekcje wirusowe). Obecne terapie, podobnie jak w przypadku chorób genetycznych, w dużej mierze zależą od rodzaju schorzenia i obejmują leczenie immunosupresyjne, stosowanie leków przeciwzapalnych lub odpowiednią dietę i fizjoterapię [3-5].

Związki pochodzenia naturalnego znane są już od wieków ze swoich biologicznych aktywności. Ze względu na wiele szlaków metabolicznych, które modulują, mogą być one rozpatrywane jako potencjalne leki na bardzo zróżnicowane choroby o odmiennej etiologii, przebiegu, czasie pojawiania się objawów czy typie dziedziczenia. Wiele z tych substancji to flawonoidy, którymi zainteresowanie rozpoczęło się na początku XX wieku kiedy to Albert Szent-Gyorgyi przypisał im właściwości przeciwszkorbutowe. Początkowo sądzono, że jest to pojedynczy związek chemiczny, który zaliczono do grupy witamin i nazwano witaminą P. Obecnie grupa flawonoidów liczy około 6000 związków [6]. Ze względu na ich budowę, właściwości oraz występowanie flawonoidy podzielone zostały na 6 głównych grup, które szczegółowo zostały przedstawione na rycinie 1.

Jednym z flawonoidów, na który zwrócono szczególną uwagę jest genisteina (5,7-dihydroksy-3-(4-hydroksyfenylo)-4H-1-benzopiran-4-on albo 4',5,7-trihydroksyizoflawon), należąca do grupy izoflawonów (Ryc. 2). Największe jej stężenie można znaleźć w roślinach strączkowych (Fabaceae), między innymi w nasionach soi, fasoli, bobu czy grochu. Genisteina dzięki swoim licznym aktywnościom biologicznym znalazła zastosowanie $\mathrm{w}$ wielu gałęziach medycyny. Dzięki swojej budowie chemicznej działa jako agonista receptorów estrogenowych ER- $\beta$, ER-a (ang. Estrogen receptor beta and alpha) oraz GPER (ang. G protein-coupled estrogen receptor 1). Właściwości te wykorzystywane są głównie podczas łagodzenia objawów przekwitania u kobiet. Efektywność działania genisteiny w tym aspekcie potwierdza fakt, że w krajach Dalekiego Wschodu, gdzie dieta bogata jest w rośliny strączkowe, objawy okresu menopauzy u kobiet są znacznie mniej nasilone [7-10].

Bazując na tej aktywności, opisywany izoflawon wykorzystywany jest również $w$ badaniach eksperymentalnych nad prewencją nowotworów piersi i prostaty lub hamowaniu angiogenezy w guzach nowotworowych. Właściwości cytotoksyczne genisteiny wobec komórek rakowych wyni-

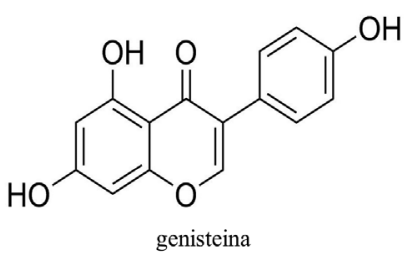

Rycina 2. Genisteina (5,7-dihydroksy-3-(4-hydroksyfenylo)-4H-1-benzopiran-4-on albo 4',5,7-trihydroksyizoflawon).

kają również ze zdolności tego związku do hamowania kinazy tyrozynowej (biorącej udział w sygnalizacji prowadzącej do wzrostu komórki) lub topoizomerazy (biorącej udział w modulacji struktury DNA) [11]. Z drugiej jednak strony część doniesień wskazuje, że genisteina może także przyspieszać proliferację niektórych komórek nowotworowych lub zmniejszać ich wrażliwość na stosowane obecnie leki podczas chemioterapii [12]. Działanie genisteiny w kontekście terapii chorób nowotworowych zależy prawdopodobnie od zastosowania konkretnej dawki $[13,14]$.

Toksyczne działanie genisteiny wobec komórek nowotworowych sugeruje obawy o jej wpływ na komórki niezmienione nowotworowo. Niektóre wyniki badań pokazują, że może ona działać mutagennie [15], chociaż inne doniesienia wskazują na jej anty-mutagenne właściwości [16]. W warunkach laboratoryjnych zaobserwowano również jej aktywność w hamowaniu proliferacji komórek [17]. Efekt ten, podobnie jak efekty genotoksyczne, również zależny jest od użytego stężenia izoflawonu [18], natomiast wartym wspomnienia jest fakt, że roczna eksperymentalna terapia genisteiną z udziałem dzieci w dawce 150 mg/kg/dzień, co jest niezwykle wysoką dawką, nie wykazała żadnych efektów niepożądanych [19].

Genisteina wykazuje również silne właściwości przeciwpasożytnicze. Wyciąg z korzenia bulwiastego rośliny strączkowej Flemingia vestita był tradycyjnym środkiem stosowanym przeciwko robakom już wśród plemion Khasi w Indiach i to właśnie opisywany izoflawon w największej mierze odpowiedzialny był za tę aktywność. Genisteinę wskazuje się jako wysoce skuteczną substancję w zwalczaniu pasożytów jelitowych, takich jak tasiemiec drobiu Raillietina echinobothrida [20], przywra Fasciolopsis buski, której żywicielem jest człowiek lub świnia, a także motylica wątrobowa (Fasciola hepatica), której żywicielem jest człowiek lub owca [21]. Izoflawon ten wywiera działania przeciwpasożytnicze dzięki właściwościom hamowania enzymów biorących udział w szlakach glikolizy i glikoneogenezy lub poprzez zaburzenia homeostazy $\mathrm{Ca}^{2+} \mathrm{i}$ aktywności tlenku azotu u pasożytów. Przeciwpasożytnicza aktywność genisteiny przebadana została również w stosunku do tasiemców, takich jak Echinococcus multilocularis i Echinococcus granulosus [22].

Genisteina wykazuje dużo więcej aktywności biologicznych, takich jak hamowanie aktywności metylotransferazy DNA, nikotynowego receptora acetylocholiny lub transportera glukozy [23]. Aktywności tego izoflawonu, takie jak działanie antyoksydacyjne, przeciwzapalne, modulacja aktywności kanału chlorkowego, indukcja autofagii, czy modulacja aktywności receptora EGFR, opisane zostały w ni- 
niejszej pracy w kontekście potencjalnego ich wykorzystania w terapii chorób genetycznych oraz immunologicznych.

\section{GENISTEINA W LECZENIU MUKOPOLISACHARYDOZ}

Mukopolisacharydozy (MPS, ang. mucopolisaccharidosis) są rzadkimi, dziedzicznymi zaburzeniami metabolicznymi spowodowanymi mutacją $\mathrm{w}$ jednym $\mathrm{z}$ genów kodujących enzymy lizosomalne degradujące glikozoaminoglikany (GAG). Są to wielocukry o nierozgałęzionych łańcuchach pełniące ważną funkcję przy łączeniu się czynników wzrostowych do ich receptorów na powierzchni komórki, a także decydujące o elastyczności tkanki łącznej. W zdrowym organizmie łańcuchy GAG są rozcinane na mniejsze fragmenty $\mathrm{w}$ specyficznych miejscach przez kilkanaście enzymów z grupy endoglukuronidaz lub endoheksozoaminidaz, a ich działanie jest ze sobą ściśle skorelowane. W wyniku działania tych enzymów powstają krótsze fragmenty, które usuwane są przez enzymy z grupy egzoglikozydaz i egzosulfataz [24]. W przypadku braku jednego z enzymów lub jego niskiej aktywności cały szlak przestaje poprawnie funkcjonować. Nieusunięte wielocukry gromadzą się w lizosomach, organellach o kwaśnym $\mathrm{pH}$, odpowiedzialnych za ich degradację.

Występuje jedenaście typów i podtypów mukopolisacharydoz, podzielonych na podstawie brakującego/defektywnego enzymu. Głównymi objawami wspólnymi dla wszystkich typów MPS są: organomegalia, nieprawidłowe formowanie się kości, sztywność stawów, niski wzrost (z wyjątkiem MPS III), zaburzenia funkcjonowania organów wewnętrznych oraz charakterystyczne rysy twarzy. Może wystąpić również upośledzenie wzroku i słuchu. Dla niektórych typów choroby (szczególnie MPS II, MPS III i części pacjentów z MPS I) typowy jest również zaburzony rozwój umysłowy [25]. Do niedawna nie było możliwości leczenia MPS, proponowano jednak kilka terapii m.in.: przeszczep szpiku lub komórek macierzystych. Niedawno opracowano metodę leczenia przyczynowego, która okazała się obiecującym rozwiązaniem w leczeniu MPS I, II, IVA, VI i VII, czyli enzymatyczną terapię zastępczą (ERT, ang. Enzyme Replacement Therapy). Polega ona na podaniu aktywnej formy brakującego enzymu [26]. Jednak terapia ta nie znalazła zastosowania w przypadku tych typów choroby, które związane są z uszkodzeniem ośrodkowego układu nerwowego, z uwagi na brak możliwości przekraczania bariery krew-mózg przez dostarczony do organizmu pacjenta dożylnie enzym. Alternatywną formą terapii dla tych chorych okazała się redukcja syntezy substratu (SRT, ang. Substrate Reduction Therapy) [27]. Terapia ERT skupia się przede wszystkim na przywróceniu odpowiedniej wydajności degradacji GAG do poziomu porównywalnego ze zdrowymi komórkami, natomiast terapia STR polega na obniżeniu poziomu ich syntezy, co również przywraca równowagę pomiędzy ich powstawaniem i usuwaniem w komórkach [28]. Najprostszą możliwością wydawałoby się użycie inhibitorów enzymów zaangażowanych w syntezę GAG. Jednak substratami $\mathrm{w}$ tych reakcjach są cukry proste, które biorą także udział w wielu innych procesach biochemicznych. Zatem ich analogi, stanowiące inhibitory kompetycyjne, najprawdopodobniej powodowałyby poważne efekty niepożądane $\mathrm{w}$ związku z zablokowaniem wielu szlaków metabolicznych. Alterna- tywną metodą jest więc obniżenie ekspresji genów syntetaz GAG (enzymów biorących udział w syntezie GAG) .

Związkiem negatywnie regulującym produkcję GAG okazała się właśnie genisteina. Stwierdzono skuteczność genisteiny w hamowaniu procesu syntezy GAG w komórkach, które pochodziły od pacjentów chorujących na różne typy mukopolisacharydoz (MPS I, II, IIIA oraz IIIB) [29]. Poszukiwanie dokładnych mechanizmów działania genisteiny wykazało, że reguluje ona negatywnie aktywność kinazy receptora naskórkowego czynnika wzrostowego (EGFR, ang. epidermal growth factor receptor) [27]. W wyniku zahamowania jego autofosforylacji, zablokowana zostaje także następująca później kaskada aktywacji kinaz, które prowadzą ostatecznie do translokacji do jądra komórkowego czynników transkrypcyjnych, które pozytywnie regulują ekspresję genów kodujących syntetazy GAG. Podsumowując, genisteina hamując ekspresję genów kodujących syntetazy GAG, prowadzi do obniżenia poziomu samych GAG w komórkach [29] (Ryc. 3).

Wykonane niedawno eksperymenty in vitro przyniosły informację o jeszcze jednym mechanizmie działania tego izoflawonu. W komórkach poddanych działaniu genisteiny zaobserwowano zahamowanie aktywności kinazy mTOR (ang. mammalian Target of Rapamycin), jednej z kluczowych kinaz regulatorowych łączącej wiele szlaków komórkowych. Konsekwencją tego zahamowania jest defosforylacja czynnika transkrypcyjnego EB (TFEB, ang. transcription factor EB). TFEB w postaci nieufosforylowanej przetransportowany zostaje do jądra komórkowego gdzie pozytywnie reguluje ekspresję genów białek lizosomalnych, które charakteryzują się obecnością specyficznej sekwencji, zwanej CLEAR (ang. Coordinated Lysosomal Expression and Regulation), w rejonie promotorowym [30] (Ryc. 4). Mechanizm działania genisteiny $\mathrm{w}$ przypadku MPS jest więc plejotropowy. Z jednej strony zahamowana zostaje synteza GAG dzięki aktywacji ścieżki zależnej od EGFR, a z drugiej GAG ulegają lizosomalnej degradacji drogą zależną od

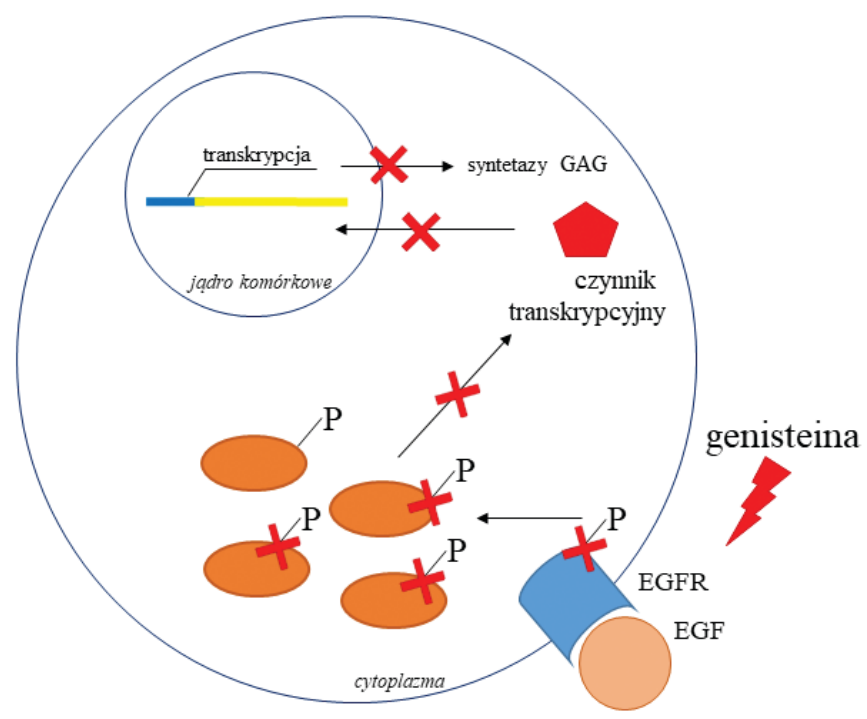

Rycina 3. Mechanizm działania genisteiny w leczeniu mukopolisacharydoz, polegający na redukcji syntezy substratu (glikozoaminoglikanów, GAG). Opis w tekście. 


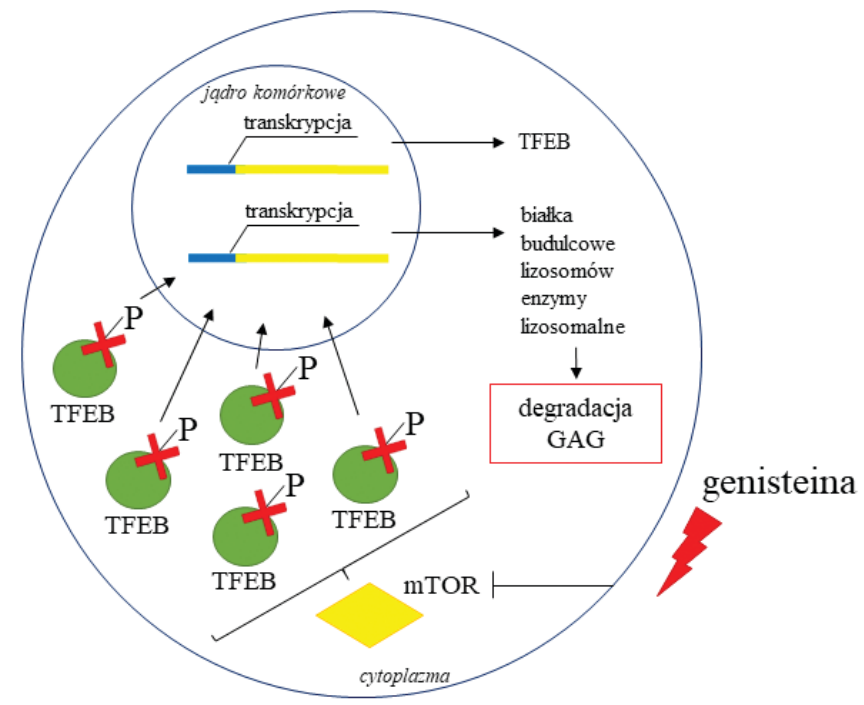

Rycina 4. Mechanizm działania genisteiny w leczeniu mukopolisacharydoz, polegający na stymulacji biogenezy lizosomów. Opis w tekście.

TFEB. Genisteina jest pierwszym i, jak do tej pory, jedynym związkiem o dwutorowym działaniu zastosowanym $\mathrm{w}$ terapii tych schorzeń [30,31].

Jedne z pierwszych krótkoterminowych badań przeprowadzonych już na modelach zwierzęcych MPS II i IIIB wykazały efektywność terapii z wykorzystaniem genisteiny w stosunku do tkanek somatycznych [32,33]. Natomiast w przypadku długoterminowych eksperymentów (trwających 8 miesięcy) $\mathrm{z}$ użyciem genisteiny $\mathrm{w}$ wysokiej dawce (160 mg/kg/dzień) w leczeniu myszy z MPS IIIB wykazano zmniejszenie akumulacji nie tylko GAG, ale również wtórnie akumulowanych gangliozydów, wzrost efektywności tworzenia synaps oraz ograniczenie procesów zapalnych w ośrodkowym układzie nerwowym. Wynikiem tych badań była całkowita normalizacja zachowania zwierząt w porównaniu do grupy kontrolnej (zwierząt chorych, którym nie podawano leku), u której obserwuje się hiperaktywność i ograniczone zdolności poznawcze [34]. Co prawda niektóre doniesienia wskazują, że genisteina nie przyczynia się do poprawy stanu myszy z MPS I, a co więcej obserwuje się $\mathrm{u}$ nich pewne objawy niepożądane, takie jak zmniejszenie długości ciała, rozwój przepukliny mosznowej oraz wodniaka moszny [35], to jednak długoterminowe badania na myszach z MPS I nie potwierdziły tych wyników, wskazując na brak specyficznych objawów niepożądanych oraz poprawę niektórych parametrów biochemicznych (W. Kobiela-Nowicka, M. Malinowska, J. Jakóbkiewicz-Banecka, G. Węgrzyn, praca w przygotowaniu).

Otwarta pilotowa próba kliniczna, która została przeprowadzona na grupie 10 pacjentów z chorobą Sanfilippo (MPS typu IIIA oraz IIIB), którym podawano przez okres 12 miesięcy preparat izoflawonów sojowych bogaty w genisteinę, dowiodła skuteczności tego preparatu w poprawie funkcji poznawczych oraz morfologii włosów, a także obniżaniu poziomu GAG w moczu pacjentów [36]. W kolejnych latach prowadzone zostały próby kliniczne I i II fazy wśród pacjentów dotkniętych tą samą chorobą $[37,38]$, które wykazały bezpieczeństwo stosowania tego flawonoidu w dawce 150 $\mathrm{mg} / \mathrm{kg} /$ dzień oraz poprawę parametrów biochemicznych w moczu i krwi pacjentów. W sierpniu 2017 roku dobiegły końca próby kliniczne III fazy, a ich wyniki są obecnie analizowane i powinny być opublikowane w niedługim czasie (EudraCT No 2013-001479-18; https:/ / www.clinicaltrialsregister.eu/ctr-search/trial/2013-001479-18/GB).

\section{POTENCJAŁ GENISTEINY W LECZENIU MUKOWISCYDOZY}

Mukowiscydoza (ang. Cystic fibrosis) należy do najczęstszych śmiertelnych schorzeń genetycznych wśród populacji kaukaskiej, występując z częstością około 1 na 2500 żywych urodzeń. Średnia długość życia osób dotkniętych tą chorobą w USA oraz Europie wynosi około 40 lat [39]. Głównym objawem mukowiscydozy jest znaczna nadprodukcja gęstego śluzu, który zalegając $w$ górnych drogach oddechowych prowadzi do przewlekłych, ostrych stanów zapalnych powodowanych przez infekcje bakteryjne, stanowiące główną przyczynę zgonów [40]. Chorych dotykają ponadto zaburzenia pracy układu pokarmowego, w szczególności zapalenia trzustki [41]. Do innych objawów należą problemy z płodnością, powodowane zatykaniem światła nasieniowodów przez gromadzący się śluz [42].

Molekularną przyczyną mukowiscydozy są mutacje w genie kodującym białko CFTR (ang. Cystic Fibrosis Transmembrane Conductance Regulator). CFTR należy do rodziny transporterów $\mathrm{ABC}$ i pełni funkcję błonowego kanału jonowego, odpowiedzialnego za transport jonów chlorkowych przez błonę komórkową. Składa się z 1480 reszt aminokwasowych, tworzących pięć domen: dwie domeny transbłonowe MSD (ang. membrane-spanning domain), każda złożona z sześciu helis alfa, połączone $\mathrm{z}$ nimi dwie domeny wiążące nukleotydy NBD (ang. nucleotide binding domain) oraz domenę regulatorową $\mathrm{R}$. W stanie nieaktywnym kanał pozostaje zamknięty, uniemożliwiając swobodny przepływ jonów. Do jego otwarcia wymagane jest przyłączenie cząsteczek ATP do domen NBD oraz fosforylacja reszt seryny domeny R [43].

Dotychczas opisano około 2000 różnych mutacji w genie CFTR, z których największą grupę, stanowiącą około $40 \%$ wszystkich mutacji zapisanych w bazach danych, stanowią mutacje typu zmiany sensu [http://www.genet.sickkids. on.ca/cftr/]. Delecja reszty fenyloalaniny $508(\Delta \mathrm{F} 508) \mathrm{w}$ domenie NBD1 stanowi natomiast najczęściej występujący defekt, spotykany u około $70 \%$ pacjentów z mukowiscydozą. Mutacja prowadząca do braku reszty fenyloalaniny w pozycji 508 białka CFTR niesie za sobą poważne konsekwencje wynikające $\mathrm{z}$ niepoprawnego fałdowania polipeptydu [44]. Domena NBD2 pozostaje w konformacji podatnej na działanie proteaz, czemu towarzyszy wzrost podatności na aktywność proteolityczną domeny NBD1 [45]. Skutkiem mutacji jest pozostawanie białka CFTR w siateczce śródplazmatycznej, co prowadzi do jego natychmiastowej degradacji. Jest ono rozpoznawane jako nieprawidłowo sfałdowany polipeptyd, po czym ulega ubikwitylacji przez system kontroli jakości białek ERQC (ang. Protein Folding and Quality Control). W konsekwencji jedynie niewielki odsetek cząsteczek białka CFTR $\Delta$ F508 zostaje przetransportowany na 


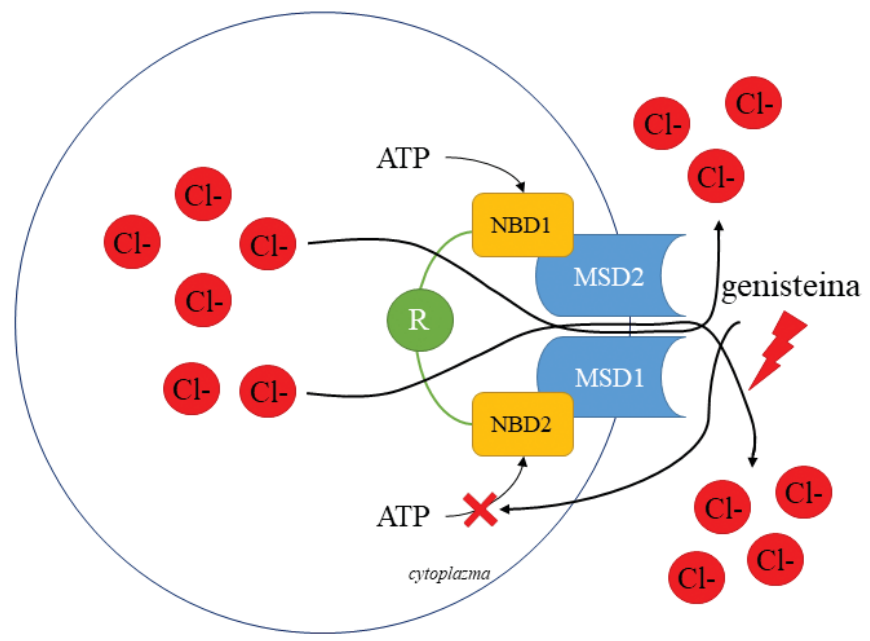

Rycina 5. Mechanizm działania genisteiny w leczeniu mukowiscydozy, polegający na bezpośrednim oddziaływaniu z domeną NBD białka CFTR, w wyniku czego zahamowana jest hydroliza ATP, a przez to zamykanie kanału jonowego. Opis w tekście.

powierzchnię komórki, gdzie może spełniać swoją funkcję [46].

Białko CFTR stanowi bezpośredni cel działania genisteiny [47]. Izoflawon ten przyłącza się poprzez domeny NBD, kontrolujące otwarcie/zamknięcie kanału chlorkowego CFTR. Otwieranie i zamykanie kanału CFTR wiąże się $\mathrm{z}$ formowaniem i rozpadem kompleksu NBD1:NBD2, kontrolowanym przez wiązanie i hydrolizę ATP. Wiązanie genisteiny wpływa na wzmożony przepływ jonów, wynikający z częstości oraz czasu otwarcia kanału. Pomimo odmiennych miejsc wiązania, genisteina wpływa na hydrolizę ATP w wyniku działania allosterycznego [48]. Zwiększenie przepustowości kanału tworzonego przez białko CFTR wiąże się ze stymulacją przez genisteinę dimeryzacji domen NBD1:NBD2, a następnie stabilizacją takiej konformacji [49]. Dzięki hamowaniu hydrolizy cząsteczki ATP związanej z NBD2, nie dochodzi do destabilizacji kompleksu NBD1:NBD2, a tym samym do zamknięcia kanału [50] (Ryc. 5).

Mechanizm działania genisteiny wydaje się być najbardziej obiecujący w przypadku mutacji, w wyniku których dojrzałe białko CFTR zostaje prawidłowo ulokowane w błonie komórkowej ale zaburzona jest funkcja otwierania kanału. Do takich zaliczają się kanały niosące zmiany reszt aminokwasowych w domenach NBD, w szczególności G551D czy G1349D [51]. Mutacja G551D prowadzi do obniżenia powinowactwa aktywatorów względem CFTR, co tłumaczyć można bliskim położeniem Gly551 w stosunku do miejsca ich wiązania. Tym samym, aby zaobserwować aktywację kanałów CFTR G551D należy stosować o wiele wyższe stężenia genisteiny (około $200 \mu \mathrm{M}$ ), niż w przypadku stymulacji białka typu dzikiego (około $30 \mu \mathrm{M}$ ) [52].

W świetle zastosowania genisteiny w leczeniu mukowiscydozy, związek ten zalicza się do grupy tzw. potencjatorów, czyli leków podwyższających aktywność kanałów jonowych tworzonych przez zmutowane białko CFTR. Geni- steina nie posiada natomiast aktywności korektorskiej wobec niepoprawnie pofałdowanego białka CFTR [53]. Z tego też względu wydawać by się mogło, że genisteina nie znajdzie zastosowania $\mathrm{w}$ terapii mukowiscydozy spowodowanej najczęściej występującą mutacją $\Delta$ F508. Powoduje ona bowiem hamowanie dojrzewania białka, a dopiero warianty CFTR pozbawione NBD2 opuszczają siateczkę śródplazmatyczną [54]. Niemniej jednak, te cząsteczki białka CFTR $\Delta$ F508, które nie zostaną zdegradowane i trafią do błony komórkowej mogą być stymulowane przez genisteinę.

Genisteina poza wyżej wymienionymi aktywnościami jest także inhibitorem aktywności kinazy tyrozynowej $[55,56]$. Hamowanie jej aktywności odbywa się poprzez łączenie się z miejscem wiązania ATP [57]. Rzadka mutacja S1045Y powoduje wzmożenie fosforylacji reszty tyrozyny w CFTR, co w konsekwencji prowadzi do ubikwitylacji tego białka i wycofania z błony komórkowej drogą endocytozy [58]. Genisteina, jako inhibitor kinazy tyrozynowej, może zatem wpływać na poziom białka CFTR S1045Y na powierzchni komórki, a dodatkowo, działając jako aktywator, stymuluje otwieranie kanału [59]. Zauważyć należy, iż $\mathrm{w}$ ten sam sposób genisteina może także stymulować transport jonów przez kanał błonowy tworzony przez zmutowaną formę CFTR $\Delta \mathrm{F} 508$.

W podsumowaniu można stwierdzić, że niska cytotoksyczność oraz szerokie spektrum działania powodują, że genisteina ma istotny potencjał terapeutyczny $\mathrm{w}$ mukowiscydozie, w przypadku szeregu mutacji w genie CFTR. Umożliwiając poprawną lokalizację kanałów i zwiększenie ich ilości w błonie komórkowej (w przypadku niektórych mutacji), przy jednoczesnym istotnym pozytywnym wpływie na ich funkcjonowanie, genisteina może stanowić potencjalny lek dla chorych na mukowiscydozę.

\section{MOŻLIWOŚCI UŻYCIA GENISTEINY W LECZENIU CHOROBY ALZHEIMERA}

Choroba Alzheimera (AD, ang. Alzheimer's disease) jest chorobą wieku podeszłego, a jej częstość występowania wzrasta z uwagi na starzejące się społeczeństwo. Obecnie liczba osób chorujących na AD przekracza 50 milionów na świecie, z czego w Polsce zdiagnozowanych jest ponad 300 000 pacjentów, a należy pamiętać, że choroba ta jest niezwykle trudna do zdiagnozowania, z uwagi na przypisywanie pierwszych jej objawów podeszłemu wiekowi.

Wyróżnia się dwie postacie AD: postać rodzinną (fAD, ang. familial $A D)$, którą diagnozuje się, kiedy w rodzinie pacjenta występują przynajmniej dwa przypadki choroby (15-40\% całej populacji chorych) oraz częściej występującą postać sporadyczną (sAD, ang. sporadic AD; 60-85\% całej populacji chorych), która nie ma uwarunkowań genetycznych. O ile postać rodzinna dziedziczona jest autosomalnie dominująco, o tyle postać sporadyczna ma podłoże wieloczynnikowe. W mózgowiu osób chorych na AD zaobserwowano odkładające się amyloidowe płytki starcze zbudowane $\mathrm{z}$ blaszek $\beta$-amyloidu ( $\beta$ A) oraz splątki neurofibrylarne (stworzone $\mathrm{z}$ hiperfosforylowanych form białka tau), które zaburzają prawidłowe funkcjonowanie neuronów oraz upośledzają transmisję cholinergiczną prowadząc do neurodege- 
neracji niektórych obszarów mózgu (głównie kory mózgu, hipokampa i ciała migdałowatego). Do najczęstszych objawów choroby zaliczamy zaburzenia myślenia abstrakcyjnego czy uszkodzenie pamięci semantycznej (wczesne stadia) oraz trudności językowe, zaburzenia pamięci długotrwałej i zmiany osobowości (późne stadia). Chorzy wyłączają się z życia społecznego i rodzinnego. Stopniowo tracą oni funkcje życiowe, co prowadzi do śmierci najczęściej w ciągu 7 lat od postawienia diagnozy [60-62].

Liczne badania nad lekami na AD opierają się na redukcji poziomów nieprawidłowo funkcjonujących białek, a tym samym ochronie neuronów przed degeneracją z powodu zaburzonych szlaków metabolicznych. $\beta$ A jest peptydem, który powstaje na skutek cięcia prekursora $\beta$ A (APP, ang. amyloid precursor protein) poprzez sekretazy ( $\beta$-sekretazy i $\gamma$-sekretazy) [63]. Kluczowym enzymem odpowiedzialnym za ten proces jest $\beta$-sekretaza 1 (BACE1) [64]. Youn i wsp. udowodnili, iż ekspresja genu kodującego BACE1 jak i jej aktywność jest znacznie zwiększona u osób z fAD. Hamowanie aktywności BACE1 jest więc jedną ze strategii terapeutycznych AD. Poszukiwania związku, który mógłby przekraczać barierę-krew mózg oraz hamować aktywność BACE1 trwają $w$ wielu laboratoriach na świecie. Jednym z przebadanych pod tym względem potencjalnych leków była genisteina, która może wykazywać właściwości inhibitora BACE1 w zależności od użytej dawki. Wykazano, że genisteina łączy się z omawianym enzymem poprzez 4 wiązania wodorowe. Silne wiązanie powstaje w miejscu allosterycznym BACE1. Hamowanie proteazy związane jest z budową strukturalną, konkretnie z obecnością grupy hydroksylowej C-5 w pierścieniu A. Wykazano, że w wyniku działania genisteiny na enzym BACE1 dochodzi do zahamowania patologicznych procesów indukowanych poprzez $\beta A$, a co za tym idzie - zahamowania apoptozy (badania przeprowadzone zarówno na liniach komórek SHSY5Y jak i na modelach zwierzęcych) [64].

Badania populacyjne wykonywane na grupach pacjentów z fAD wykazały również obecność mutacji w genie apolipoproteiny E (ApoE), transportującej cholesterol w ośrodkowym układzie nerwowym pomiędzy komórkami glejowymi a neuronami oraz ułatwiającej transport lipidów i naprawę uszkodzeń neuronalnych. ApoE odpowiada także za regulację homeostazy lipidów (wiąże się z receptorami na powierzchni komórki w celu dostarczenia lipidów wraz z $\beta$ A) oraz za regulację agregacji $\beta \mathrm{A}$ i jego usuwanie $\mathrm{z}$ ośrodkowego układu nerwowego. ApoE występuje w 3 izoformach: ApoE2, ApoE3, ApoE4. Mutacja w ApoE4 jest najsilniejszym genetycznym czynnikiem ryzyka wystąpienia $A D$, gdyż u nosicieli mutacji tej izoformy dochodzi do obfitego odkładania się $\beta$ A [65]. Mózg należy do organów najbogatszych w cholesterol, który jest wykorzystywany do tworzenia połączeń neuronalnych. Zaburzona homeostaza cholesterolu może wpłynać na powstawanie i usuwanie $\beta$ A oraz APP, a w konsekwencji w dużej mierze przyczynić się do wystąpienia AD. Park i wsp. udowodnili, że u myszy z niedoborem ApoE oraz z podwyższonym poziomem cholesterolu dochodzi do stymulacji przetwarzania APP oraz istotnego zwiększenia odkładania się $\beta A$. Jednakże podanie genisteiny zmniejsza poziom białek: $\beta$ A oraz APP. Ponadto pod wpływem opisywanego flawonoidu dochodzi do obniżenia poziomu enzymów

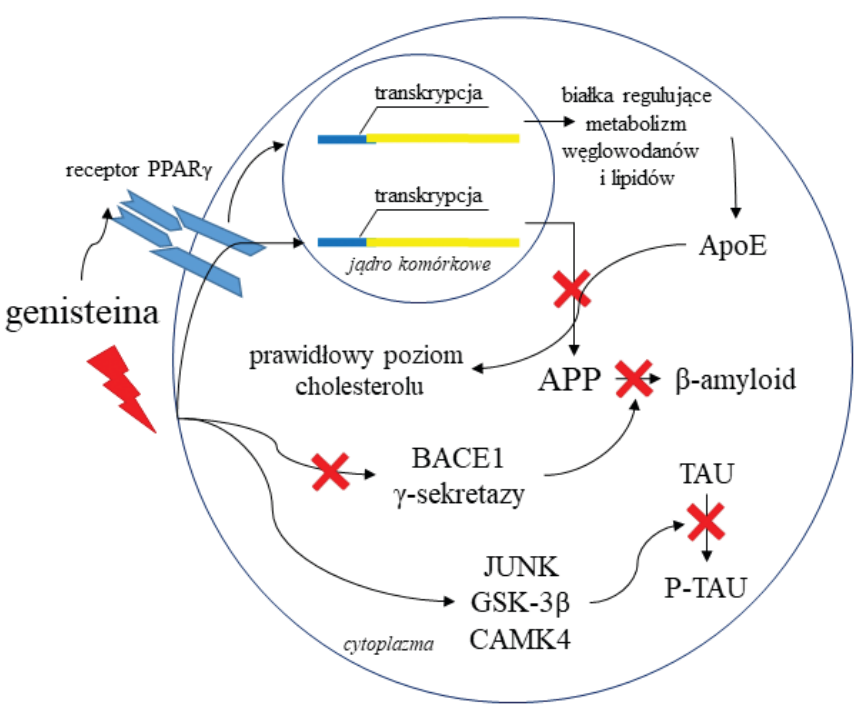

Rycina 6. Mechanizmy działania genisteiny w leczeniu choroby Alzheimera Opis w tekście.

biorących udział w powstawaniu $\beta$ A (BACE1, $\gamma$-sekretazy) [66]. Badania nad myszami z hipercholesterolemią wykazały, że genisteina znosi efekty zaburzenia metabolizmu cholesterolu, który ma związek $z$ akumulacja $\beta$ A. Izoflawon ten obniża poziom ekspresji genów zarówno APP, jak i aktywność kinaz odpowiedzialnych za fosforylację białka tau (kinaza GSK-3 $\beta$ i JNK) [66]. Kolejne badania nad mysim modelem AD wykazały, że genisteina aktywuje inne ugrupowanie receptora PPARY [67]. Receptory te są czynnikami transkrypcyjnymi, które regulują ekspresję genów odpowiadających za m.in. metabolizm węglowodanów i lipidów. Uczestniczą one w różnego rodzaju zaburzeniach metabolicznych takich jak np. otyłość czy insulinooporność [68]. Skutkiem tej aktywacji jest uwolnienie ApoE i przywrócenie prawidłowego metabolizmu cholesterolu w komórkach nerwowych [67]. Badania na szczurzym modelu AD dowodzą, że genisteina poprawia pamięć i zdolność uczenia się zwierząt. Wyniki testów behawioralnych (takich jak labirynt $Y$, test biernego unikania miejsca $\mathrm{i}$ test labiryntu wodnego Morrisa) przeprowadzonych $\mathrm{u}$ grupy, której podawano genisteinę były znacząco lepsze niż wyniki grupy kontrolnej.

Kolejnym prawdopodobnym mechanizmem działania genisteiny jest regulacja aktywności zależnej od wapnia/ kalmoduliny kinazy białkowej CAMK4, która może fosforylować między innymi białko tau. Badania na szczurzym modelu AD wykazały, że akumulacja $\beta$ A prowadzi do aktywacji CAMK4, a w konsekwencji aktywacji następującej później kaskady kinaz (CAMKK1, CALM i CREB). Zaproponowanym przez autorów mechanizmem działania genisteiny jest bezpośrednie wiązanie się izoflawonu do receptora estrogenowego, a co za tym idzie obniżenie stężenia wapnia w komórce. Natomiast obniżenie poziomu wapnia hamuje aktywność wymienionej kaskady kinaz, w tym kinazy CAMK4. Efektem takiej regulacji jest zmniejszenie poziomu hiperfosforylacji białka tau, a także obniżenie poziomu splątków neuofibrylarnych w mózgu szczurów z AD, skutkując poprawą pamięci i zdolności poznawczych [69]. Opisane szlaki prowadzące do redukcji poziomu białek powodujaccych AD zobrazowane 
zostały na rycinie 6 . W trakcie rozwoju choroby dochodzi do zwiększonej ekspresji genów kodujących białka będące głównymi elementami składowymi mitochondrialnego szlaku apoptotycznego. Kolejne badania in vivo wykazały, że genisteina zmniejsza efektywność ekspresji genów kodujących proapoptotyczny cytochrom c, Bax oraz kaspazę 3, a także redukuje ich immunoreaktywność. Efektem tego jest redukcja liczby komórek apoptotycznych znajdujących się w hipokampie chorych zwierząt, co prowadzi do ochrony przed rozwojem neurodegeneracji [70].

Stres oksydacyjny jest uważany za kolejną z przyczyn progresji AD. Ujawnia się jako upośledzenie równowagi pomiędzy reaktywnymi formami tlenu (ROS), a zdolnością komórek do usuwania reaktywnych produktów, bądź też naprawy szkód przez nie wyrządzonych. Badania in vivo ludzkich zróżnicowanych neuronalnych linii komórkowych (SK-N- BE i NT-2) wykazały powiązanie między produktami utleniania cholesterolu, a wiązaniem się $\beta \mathrm{A}$ do komórek. 24-hydroksycholesterol zwiększa przyczepność dużych ilości $\beta$ A do błony komórkowej neuronów, a tym samym przyczynia się do indukowanej przez $\beta A$ (1-42) apoptozy oraz nekrozy tych komórek. Działanie tego związku zależy od lokalnego wzrostu poziomu ROS, głównie nadtlen$\mathrm{ku}$ wodoru, co powoduje zaburzenie równowagi redoks neuronów. Inkubacja komórek $\mathrm{z}$ antyoksydantami m.in. genisteiną znosi efekty powodowane przez $\beta$ A poprzez zapobieganie powstawania prooksydanta - 24-hydroksycholesterolu [71]. Kolejne badania przyniosły podobny efekt. Genisteina testowana na szczurach z wstrzykniętym $\beta$ A (140) wewnątrz hipokampa zmniejszała zawartość aldehydu dimalonowego (MDA), jednego z markerów stresu oksydacyjnego [72]. Opisywany związek może również osłabiać cytotoksyczność i stan zapalny wywołany przez fragmenty ßA25-35, które uważane są za toksyczne. Badania wykazały odwrócenie pod wpływem genisteiny indukowanej fragmentami $\beta$ A25-35 podwyższonej ekspresji receptora TLR4 i czynnika transkrypcyjnego NF-kB, które pośredniczą $\mathrm{w}$ odpowiedzi immunologicznej [73].

Ciekawym doniesieniem jest fakt, że obniżony poziom endogennego estrogenu znacznie zwiększa częstość występowania AD [74]. Zatem stosowanie genisteiny w leczeniu AD jest tym bardziej zasadne, że izoflawon ten wykazuje strukturalne podobieństwo do estrogenu, dzięki czemu może zastąpić te braki [64].

\section{GENISTEINA JAKO POTENCJALNY LEK W CHOROBIE HUNTINGTONA}

Choroba Huntingtona (HD, ang. Huntington's disease) jest genetyczną, postępującą chorobą neurodegeneracyjną, dziedziczoną w sposób autosomalny dominujący. Spowodowana jest mutacją polegającą na ekspansji trójki nukleotydów CAG w 1 eksonie genu IT15 kodującym białko huntingtynę (HTT). Liczba powtórzeń CAG przekraczająca 40 kopii jest przyczyną powstawania długiego ciągu reszt poliglutaminowych w sekwencji aminokwasowej tego białka co uniemożliwia jego prawidłowe fałdowanie. W konsekwencji zmutowana huntingtyna (mHTT) odkłada się w komórkach, głównie nerwowych i mięśniowych, w postaci nierozpuszczalnych, niemożliwych do usunięcia agregatów upośledzając prawidłowe ich funkcjonowanie. Charakterystyczna atrofia i utrata neuronów występująca w HD prowadzi do pojawienia się klasycznej triady objawów, na które składają się zaburzenia motoryki, utrata zdolności poznawczych oraz zmiany emocjonalne. Choroba prowadzi do śmierci w ciągu 15-20 lat od rozpoznania [75].

Dokładny mechanizm jakim fizjologiczne procesy komórkowe ulegają uszkodzeniu przez mHTT nie jest do końca poznany, aczkolwiek efekty toksyczne w rejonie cytoplazmy obejmują zaburzenie działania białek opiekuńczych, proteasomu i autofagii, co może powodować akumulację nieprawidłowo sfałdowanych białek i innych składników komórkowych. Dowiedziono także, że transport pęcherzykowy, w którym bierze udział prawidłowa forma HTT, zachodzi z dużo mniejszą wydajnością. Bezpośrednie oddziaływania między mHTT i mitochondriami prowadzą do nadmiernej produkcji reaktywnych form tlenu (ROS) oraz w wyniku zmian metabolizmu glukozy - zmniejszenia produkcji ATP [76].

Badania z wykorzystaniem genisteiny w eksperymentalnej terapii HD przeprowadzono głównie z wykorzystaniem szczurzego modelu indukowanego kwasem 3-nitropropionowym (3-NPA). Indukcja 3-NPA powoduje neurodegenerację przez zaburzenie metabolizmu mitochondrialnego, co prowadzi do uwolnienia reaktywnych form tlenu, zaburzenia energetyki komórkowej i aktywacji mikrogleju, co z kolei jest przyczyną przewlekłego stanu zapalnego oraz indukcji szlaków apoptotycznych. Natomiast aktywowany mikroglej uwalnia mediatory prozapalne, takie jak cytokiny i aminokwasy, pobudzając i zwiększając ekspresję COX-2 i iNOS, który dodatkowo usprawnia produkcję ponadtlenków i tlenków azotu. Obniżony poziom ATP może być uznany za bezpośrednią przyczynę śmierci komórkowej wywołanej przez 3-NPA, gdyż działa on jako nieodwracalny inhibitor dehydrogenzay bursztynianowej, enzymu przekształcającego bursztynian w fumaran podczas cyklu Krebsa, czego efektem jest zablokowanie transportu elektronów w łańcuchu oddechowym. Podanie 3-NPA powoduje zatem spadek poziomu ATP, zwłaszcza w mięśniach i mózgu (głównie w obszarze prążkowia), i co za tym idzie, wpływa negatywnie na prawidłową aktywność elektryczną mózgu [77]. Tak znaczny spadek energii prowadzi do gwałtownego spadku wagi i temperatury ciała szczurów. Kwas 3-NPA prowadzi również do wzrostu ekspresji genu jednego z białek proapoptotycznych, Bax. Działanie proapoptotyczne tego białka polega na ułatwianiu uwalniania cytochromu c poprzez tworzenie $\mathrm{w}$ mitochondriach porów. Zaburzenie stosunku białek proapoptotycznych do białek anty-apoptotycznych Bax/Bcl-2 pod wpływem 3-NPA prowadzi do szybkiego wejścia komórek nerwowych na drogę programowanej śmierci komórki. Podsumowując, u zwierząt po iniekcji 3-NPA śmierć komórek nerwowych następuje $\mathrm{w}$ wyniku zaburzeń w metabolizmie mitochondriów co prowadzi do uwalniania reaktywnych form tlenu, zaburzeń energetyki komórki oraz indukcji szlaków apoptotycznych. Model ten dobrze więc odzwierciedla wszystkie wtórne zmiany biochemiczne pojawiające się w komórkach pacjentów cierpiących na HD spowodowanych agregacją mHTT [78]. 
Menze i wsp. wykazali, że podawanie genisteiny w dawce $20 \mathrm{mg} / \mathrm{kg}$ szczurom $\mathrm{z}$ indukowaną HD przywraca prawidłowy poziom ATP $w$ tkance nerwowej oraz prawidłową strukturę histologiczną prążkowia. Ponadto u szczurów tych zaobserwowano spadek poziomu indukowanej cyklooksygenazy oraz syntazy tlenku azotu (które aktywowane są zwykle pod wpływem czynników związanych ze stanem zapalnym). Nieobecność glejozy dodatkowo potwierdza działanie przeciwzapalne genisteiny. Ponadto autorzy dowiedli, że opisywany izoflawon posiada zdolność do normalizacji stosunku białek Bax/Bcl-2, co ogranicza ilość komórek znajdujących się na drodze do apoptozy [78].

Warto nadmienić jednak, że iniekcja 3-NPA nie prowadzi u gryzoni do objawów obserwowanych u pacjentów z HD. Same pląsawiczne ruchy jako główny objaw HD po traktowaniu 3-NPA nigdy się nie rozwijają. Gryzonie traktowane 3-NPA charakteryzują się za to sennością, nieskoordynowanym chodem z pokładaniem się i turlaniem, a ostatecznie leżeniem na boku lub brzuchu. Objawy te tylko częściowo odzwierciedlają ludzką postać HD. Pomimo tego szczury z HD indukowaną za pomocą 3-NPA charakteryzują się istotną poprawą aktywności lokomotorycznej oraz poprawą zdolności poznawczych, a także utrzymaniem prawidłowej masy i temperatury ciała po podawaniu genisteiny [78].

Niedawne badania wykazały również inny mechanizm działania genisteiny niż działanie przeciwzapalne, antyoksydacyjne czy hamujące procesy apoptozy. Badania nad komórkowym modelem HD wykazały, że izoflawon ten posiada zdolność do indukcji usuwania agregatów mHTT. Inkubacja komórek eksprymujących zmutowany i prawidłowy wariant HTT w obecności genisteiny wykazała zależny od stężenia spadek poziomu mHTT przy jednoczesnym utrzymaniu stałego poziomu prawidłowej HTT. Nie tylko rozpuszczalna forma białka, ale też tworzone przez nią agregaty ulegają usunięciu w komórkach traktowanych opisywanym izoflawonem [79]. Działanie to występuje dzięki indukcji procesu autofagii, jednej z głównych dróg usuwania makrocząsteczek w komórkach [80] (Ryc. 7). Autofagia jest zachowanym $\mathrm{w}$ ewolucji procesem zachodzącym we wszystkich komórkach eukariotycznych. Polega na otoczeniu makrocząsteczek przeznaczonych do degradacji podwójną błoną i zamknięciu ich w pęcherzyku zwanym autofagosomem. Autofagosom ulega następnie fuzji z lizosomem, a wnętrze pęcherzyka strawione zostaje przez kwaśne hydrolazy [80]. Mechanizm indukcji autofagii przez genisteinę częściowo sugerowany był już przy badaniach nad wykorzystaniem genisteiny w leczeniu MPS, gdyż stymulacja czynnika transkrypcyjnego EB (TFEB) prawie zawsze równoznaczna jest $\mathrm{z}$ indukcją procesu autofagii. Induktory procesu autofagii są potencjalnymi kandydatami jako leki głównie z powodu specyficzności tego procesu względem nieprawidłowych form białek (o czym świadczy m.in. stały poziom zdrowej formy HTT po traktowaniu genisteiną), gdyż prawidłowe ich formy pełnią $\mathrm{w}$ organizmie wiele ważnych funkcji [79].

Podsumowując, genisteina $\mathrm{w}$ przypadku HD usuwa zarówno pierwotną przyczynę choroby, czyli mHTT, jak i wpływa pozytywnie na wtórne zmiany spowodowane jej

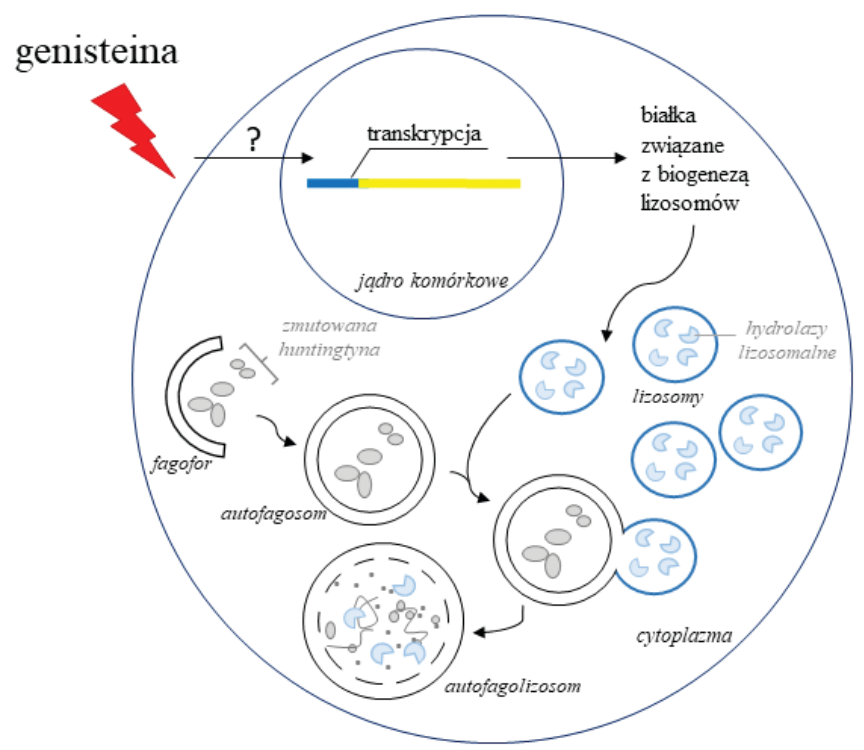

Rycina 7. Mechanizm działania genisteiny w leczeniu choroby Huntingtona, polegający na stymulacji procesu autofagii. Opis w tekście.

pojawieniem się, czyli stan zapalny, wzrost poziomu reaktywnych form tlenu czy indukcja apoptozy.

\section{PRÓBY UŻYCIA GENISTEINY W CHOROBIE PARKINSONA}

Choroba Parkinsona (PD, ang. Parkinson's disease) jest jedną z najczęściej występujących chorób neurodegeneracyjnych, która atakuje głównie neurony produkujące dopaminę $\mathrm{w}$ istocie czarnej śródmózgowia. Objawy na ogół rozwijają się powoli przez lata. W początkowej fazie choroby najczęściej występuje drżenie spoczynkowe, sztywność mięśniowa, powolność ruchów (bradykinezja) i trudności z chodzeniem. Innymi objawami są zaburzenia poznawcze i psychiczne takie jak demencja i depresja [81]. Bezpośrednią przyczyną PD są triplikacje w genach kodujących a-synukleinę, znalezione głównie $\mathrm{w}$ postaci spontanicznej (sPD, ang. spontaneous PD) i niezdefiniowane mutacje $\mathrm{w}$ genach kodujących parkininę (głównie postać rodzinna, fPD, ang. familial PD). Mówi się jednak, że mutacje są przyczyną tylko części przypadków PD, zaś inne czynniki wywołujące tę chorobę nie zostały dobrze poznane. W komórkach osób cierpiących na PD obserwuje się powstające tzw. ciałek Lewy'ego, które hamują wydzielanie jednego z neurotransmiterów, dopaminy. Choroba jest nieuleczalna i prowadzi do stopniowej niepełnosprawności, unieruchomienia i całkowitej zależności od opiekunów. Schorzenie to samo w sobie nie prowadzi do śmierci, jednak nasilające się objawy choroby znacznie pogarszają jakość życia. Śmierć następuje w wyniku powikłań, najczęściej zapalenia płuc. Badania epidemiologiczne pokazują, że PD dotyka częściej mężczyzn niż kobiety i również u mężczyzn postępuje szybciej. Nie jest znany mechanizm tej dysproporcji względem płci, jednak wiadomo, że estrogeny (żeńskie hormony płciowe) mogą wykazywać działanie ochronne przeciwko degeneracji neuronów dopaminergicznych wywołanej stresem oksydacyjnym [81]. 
W badaniach Kaula i wsp. linię komórkową N27 traktowaną nadtlenkiem wodoru oraz $25 \mu \mathrm{M}$ genisteiną analizowano pod kątem cięcia wrażliwej na stres oksydacyjny kinazy PKCס, które to cięcie prowadzi do jej aktywacji i w następstwie do apoptotycznej śmierci komórek modelowych dla PD. Wykazano, że genisteina hamuje proteolityczną aktywację kinazy PKC 8 , a co za tym idzie apoptozę [82]. Genisteinę badano również ze względu na jej właściwości inhibitora kinazy tyrozynowej. Badania te wykonywane były na modelu myszy $z$ fenotypem PD indukowanym manebem i parakwatem. Mechanizm działania parakwatu polega na wytworzeniu anionu ponadtlenkowego, który ulega szeregowi przekształceń $\mathrm{w}$ rodnik hydroksylowy. Wytworzony rodnik reaguje łatwo z nienasyconymi kwasami tłuszczowymi, tworząc wodoronadtlenki lipidów, które inicjują reakcję łańcuchową rodników lipidowych powodując oksydacyjne uszkodzenia komórek prowadzące do zwiększonej płynności, przepuszczalności i utraty integralności błony komórkowej. Natomiast działanie manebu koncentruje się na zaburzeniu funkcji mitochondriów, co prowadzi do zakłócenia metabolizmu energetycznego komórek. Wspólne traktowanie manebem i parakwatem uszkadza neurony dopaminergiczne prowadząc do zaburzeń funkcji motorycznych zwierząt. Istnieją sugestie, że modulacja aktywności kinazy tyrozynowej (którą charakteryzuje się genisteina) bierze udział $\mathrm{w}$ transdukcji sygnału do regulacji ekspresji genu syntazy tlenku azotu $[83,84]$. Wspomniane wyżej badania wykazały, że genisteina znacząco hamuje ekspresję genu indukowalnej formy syntazy tlenku azotu, obniża poziom azotanów i redukuje peroksydację lipidów. Oprócz tego genisteina częściowo przywraca liczbę TH-immunoreaktywnych neuronów do poziomu kontroli [85]. Kolejne badania wykazały, że kofeina może redukować działanie manebu i parakwatu, a u myszy, którym podawano równocześnie genisteinę i kofeinę ta redukcja była bardziej widoczna [86]. Inne badania przeprowadzone zostały na szczurzym modelu indukowanym neurotoksyną 6-hydroksydopaminą (6-OHDA). 6-OHDA podlega enzymatycznej obróbce $\mathrm{w}$ neuronach dopaminergicznych czego efektem jest powstawanie reaktywnych form tlenu, które $z$ jednej strony uszkadzają materiał genetyczny, a z drugiej upośledzają aktywność kompleksu I łańcucha oddechowego $\mathrm{w}$ mitochondriach. Badania $\mathrm{z}$ udziałem genisteiny wykazały, że izoflawon ten podany prewencyjnie przed wywołaniem objawów choroby wykazuje działanie neuroprotekcyjne przeciwko działaniu 6-OHDA na neurony dopaminergiczne [87].

\section{NEUROPROTEKCYJNE WŁAŚCIWOŚCI GENISTEINY W MYSIM MODELU STWARDNIENIA ZANIKOWEGO BOCZNEGO}

Stwardnienie zanikowe boczne (ALS, ang. amyotrophic lateral sclerosis) jest chorobą neurodegeneracyjną, w przebiegu której dochodzi do uszkodzenia motoneuronów obwodowych i ośrodkowych. Objawia się ona postępującym zanikiem mięśni, osłabieniem oraz drżeniem mięśniowym. Około 5-10\% wszystkich przypadków ALS to postać rodzinna (fALS, ang. familial ALS). U 20\% pacjentów dotkniętych tą postacią choroby identyfikuje się mutację w genie SOD1, kodującym cynkowo-miedziową dysmutazę ponadtlenkową (CuZnSOD, ang. copper-zinc superoxide dismutase), główny komórkowy enzym antyoksydacyjny. W przeważającej części przypadków dziedziczenie ALS jest autosomalne dominujące [88]. Analizując dostępne piśmiennictwo można stwierdzić, że jest to choroba wielokomórkowa (oprócz neuronów ruchowych uszkodzeniu ulegają również komórki glejowe), ale także wieloukładowa. Układ ruchu jest uszkadzany najwcześniej i w największym stopniu. Zwiększona podatność neuronów ruchowych na wystąpienie zmian patologicznych wynika z ich dużych rozmiarów, ale także intensywnego metabolizmu, co czyni je wyjątkowo wrażliwymi na stres oksydacyjny. Patogeneza ALS jest złożona i wciąż nie w pełni poznana. Wśród mechanizmów leżących u jej podłoża wymienia się obok stresu oksydacyjnego, toksyczność kwasu glutaminowego, nieprawidłowe funkcjonowanie mitochondriów, stres siateczki śródplazmatycznej, agregację białek, nieprawidłowe funkcjonowanie szkieletu komórkowego, zaburzenia transportu aksonalnego, proces zapalny lub czynniki genetyczne [89]. Terapia ALS powinna mieć zatem charakter skojarzony i wpływać na różne potencjalne mechanizmy neurodegeneracji.

Pierwsze doniesienia dotyczące neuroprotekcyjnych właściwości genisteiny pochodzą z lat 90-tych i związane są z mysim modelem rodzinnej postaci tego schorzenia. Heterozygotyczne myszy transgeniczne posiadające mutację w genie SOD-1 otrzymywały dwukrotnie w ciągu dnia genisteinę $\mathrm{w}$ dawce $16 \mathrm{mg} / \mathrm{kg}$. Za początek rozwoju fALS uznawano pierwszy dzień wystąpienia niedowładu lub porażenia mięśni. Wykazano, że genisteina opóźnia początek rozwoju choroby u samców, ale nie u samic. Sugeruje to prawdopodobny udział estrogenu, jako czynnika odpowiedzialnego za zależne od płci nasilenie objawów w przebiegu fALS [90]. Ponadto późniejsze badania potwierdziły, że plejotropowy charakter aktywności genisteiny, obejmujący właściwości antyoksydacyjne i hamowanie aktywności kinazy tyrozynowej JAK3, przyczynia się do wydłużenia czasu przeżycia myszy z modelem ALS średnio o dwa miesiące, porównując ze zwierzętami z grupy kontrolnej. Jak wiadomo, układ przekaźnikowy JAK/Stat (kinaza tyrozynowa Janus/sygnał transdukcji i aktywacji transkrypcji) jest wykorzystywany przez wiele cytokin, czynników wzrostu, ale odgrywa istotną rolę również w przebiegu apoptozy czy w patogenezie chorób neurodegeneracyjnych [91]. Wykazano także przeciwzapalne działanie genisteiny (w stężeniu $1 \mu \mathrm{M}) \mathrm{w}$ odniesieniu do szczurzych komórek mikrogleju (HAPI) aktywowanych lipopolisacharydem. Efekt ten był związany z zahamowaniem aktywności czynnika regulującego interferony (IRF-1), fosforylacją Stat1 oraz zmniejszeniem poziomu białka chemotaktycznego monocytów MCP1 i interleukiny- 6 .

Wiele doniesień wskazuje na zdolność estrogenu do ograniczania uszkodzeń mózgu i zwiększania odsetka neuronów, które nie uległy uszkodzeniom $\mathrm{w}$ eksperymentalnych modelach choroby Alzheimera, Parkinsona czy stwardnienia rozsianego. Te neuroprotekcyjne właściwości wynikają z ograniczenia uwalniania czynników prozapalnych i redukcji aktywacji mikrogleju. Jednakże odkąd potwierdzono, że podawanie estrogenu może wywierać także szereg szkodliwych efektów, istotne jest znalezienie innych alternatywnych form terapii, charakteryzujących się mniejszą liczbą efektów niepożądanych. Wśród takich potencjal- 
nie użytecznych związków, wymienić należy genisteinę i daidzeinę (inny izoflawon), których stosowanie $\mathrm{w}$ niskich dawkach ogranicza efekty niepożądane, podtrzymując jednocześnie ich korzystne właściwości neuroprotekcyjne [92].

\section{IMMUNOMODULACYJNE WŁAŚCIWOŚCI GENISTEINY}

Wieloletnie badania dowodzą, że pomimo właściwości antyoksydacyjnych oraz przeciwnowotworowych [11], genisteina i inne izoflawonoidy wykazują silne działanie immunoregulacyjne (przeciwzapalne), które zostało potwierdzone zarówno w badaniach podstawowych, przedklinicznych, jak również w obserwacjach klinicznych. Ponadto $\mathrm{w}$ badaniach epidemiologicznych odnotowuje się istotną zależność pomiędzy niższą zapadalnością na niektóre chroniczne choroby $\mathrm{u}$ ludzi a stosowaniem diety bogatej w soje zawierającą aktywne związki fitoestrogenowe, w tym genisteinę [93]. Dlatego coraz częściej rozważa się wykorzystanie genisteiny w leczeniu i profilaktyce chorób autoimmunizacyjnych, alergicznych i innych chorób zapalnych o przebiegu chronicznym, w których komórkowe mechanizmy regulatorowe są zaburzone. Dokładny mechanizm działania genisteiny na komórki układu immunologicznego nie jest poznany, jednak uważa się, że pełni ona funkcję częściowego agonisty dla receptora estrogenu (ER, ang. estrogen receptor), którego aktywacja w komórkach układu immunologicznego może prowadzić do uruchomienia mechanizmów immunoregulatorowych $[94,95]$. Pośrednim potwierdzeniem powyższej hipotezy jest fakt, że zaburzenia związane z produkcją estrogenów u kobiet w okresie menopauzalnym są przyczyną zwiększonej predyspozycji do rozwoju chorób autoimmunizacyjnych w tej grupie [96], a terapia z wykorzystaniem genisteiny hamuje rozwój autoimmunologicznej choroby jajników prowadząc do poprawy ich morfologii i wzrostu produkcji hormonów żeńskich w modelu mysim [97].

Hamujący efekt działania genisteiny na szereg procesów komórkowych, w których zaangażowane są liczne cząsteczki sygnałowe, tj. kinazy (EGFR, PDGFR, receptor insulinowy, Abl, Fgr, Itk, Fyn, Src, ERK1/2, MAPK, i PI3K/ Akt) oraz czynniki transkrypcyjne (np. NF-kB), wskazuje na potencjalne wykorzystanie tego związku w terapii chorób nowotworowych [98]. Powyższe obserwacje mogą również tłumaczyć wyciszający efekt działania genisteiny na poszczególne komórkowe elementy układu immunologicznego związane zarówno z pierwotną, jak również wtórną (nabytą) odpowiedzią immunologiczną [93]. Szczególnie wrażliwe na działanie genisteiny $\mathrm{w}$ hodowlach komórkowych okazały się komórki prezentujące antygen, tj. komórki dendrytyczne, monocyty oraz makrofagi pochodzące zarówno od myszy, jak i człowieka. Efektem działania genisteiny na powyższe hodowle komórkowe było m.in. (i) zahamowanie wydzielania prozapalnej IL-6, (ii) blokada aktywności NFкB, STAT-1, PGE 2, COX-2, i NOS, (iii) spadek poziomu ekspresji genów receptorów powierzchniowych CD86 i MHC II, (iv) jak również wzrost poziomu białka p53 w komórkach [99-101]. Obecność genisteiny w ludzkich hodowlach jednojądrzastych komórek krwi obwodowej (PBMC) prowadziła do spadku indukowanej proliferacji, zahamowania aktywności NF-kB i spadku poziomu sekrecji prozapalnej IL-2 [102,103]. Przeciwzapalna aktywność genisteiny zo- stała również potwierdzona w hodowlach komórek tucznych, bazofili i eozynofilii, bezpośrednio zaangażowanych w rozwoju chorób alergicznych i anafilaksji. Efektem działania genisteiny na powyższe komórki było zahamowanie sekrecji histaminy (głównego czynnika reakcji alergicznej) w reakcji niezależnej oraz zależnej od receptora $\mathrm{Fc}_{\varepsilon} \mathrm{R}$ i IgE [104-106].

Powyższe obserwacje skłoniły badaczy do podjęcia prób przedklinicznych, z wykorzystaniem mysich oraz szczurzych modeli chorób zapalnych, oraz badań klinicznych. Doustna aplikacja genisteiny hamowała rozwój astmy oraz reakcji anafilaktycznej w alergii pokarmowej na przykładzie modeli mysich [107-109]. W obu przypadkach dochodziło odpowiednio do zahamowania aktywności eozynofilii oraz komórek tucznych $[107,108]$. Badania z wykorzystaniem materiału ludzkiego pochodzącego od pacjentów cierpiących na astmę alergiczną potwierdzają immunoregulacyjne właściwość genisteiny na aktywność eozynofilii, w układzie ex vivo [110], a dieta bogata $\mathrm{w}$ izoflawonoidy zawartych $\mathrm{w}$ soi jest kojarzona z redukcją występowania przewlekłej obturacyjnej choroby płuc [111] oraz z poprawą wydolności płuc u pacjentów z astmą [112]. W szczurzym modelu zapalenia okrężnicy zaindukowanej kwasem 2,4,6-trinitrobenzenosulfonowym dochodziło do spadku odpowiedzi zapalnej po aplikacji genisteiny [113], jednak długotrwała terapia prowadziła do zaostrzenia objawów [114]. Immunoregulacyjne właściwości genisteiny zostały natomiast potwierdzone $\mathrm{w}$ mysich modelach chorób autoimmunizacyjnych, w rozwoju których ważną rolę pełnią prozapalne limfocyty Th1, tj. reumatoidalnego zapalenia stawów [115], tocznia [116], cukrzycy typu I [117] i stwardnienia rozsianego [118]. W ostatniej wymienionej jednostce chorobowej dochodziło do wyciszenia objawów klinicznych, które były zarazem skojarzone ze spadkiem prozapalnej populacji limfocytów Th17 oraz indukcją limfocytów T regulatorowych [118]. Co więcej, porównawcze badania kliniczne z zastosowaniem podwójnie ślepej próby wykazały, że podawanie genisteiny pacjentom z chorobą Hashimoto (przewlekłym limfocytowym zapaleniem tarczycy) prowadziło do istotnej poprawy markerów serologicznych, m.in. wzrostu $\mathrm{T}_{4}$ oraz spadku poziomu TSH i autoprzeciwciał anty-TPO/TG w porównaniu do grupy przyjmującej placebo. Autorzy tej pracy sugerują immunosupresyjny efekt działania terapii na ekspansję prozapalnej populacji limfocytów Th1 [119].

Podsumowując, fitoestrogeny zawarte w pożywieniu bogatym w soję wykazują endokrynne działanie na układ immunologiczny. Nie jest wykluczone zatem, że związki te mogą w nieodpowiednio wysokim stężeniu być również odpowiedzialne za patologiczne i epigenetycznie zmiany w funkcjonowaniu naszego organizmu [95]. Przykładem takiego zjawiska może być predyspozycja do rozwoju choroby Kawasaki (zespołu skórno-śluzówkowo-węzłowego objawiającego się uogólnionym zapaleniem tętnic) u dzieci będących na diecie bogatej w produkty sojowe zawierające flawonoidy [120].

\section{PODSUMOWANIE}

Genisteina wykazuje bardzo szeroki zakres działania biologicznego, co czyni ją związkiem o wielu możliwych zasto- 
Tabela 1. Mechanizmy działania genisteiny w różnych chorobach.

\begin{tabular}{|c|c|c|c|c|c|c|c|}
\hline \multirow[b]{2}{*}{ Choroba $^{a}$} & \multicolumn{7}{|c|}{ Mechanizm działania genisteiny ${ }^{\mathrm{b}}$} \\
\hline & $\begin{array}{l}\text { Działanie bezpośrednie } \\
\text { na docelowe białko }\end{array}$ & $\begin{array}{l}\text { Redukcja syntezy } \\
\text { substratu }\end{array}$ & $\begin{array}{l}\text { Stymulacja } \\
\text { autofagii }\end{array}$ & $\begin{array}{l}\text { Hamowanie } \\
\text { apoptozy }\end{array}$ & $\begin{array}{l}\text { Działanie } \\
\text { estrogenne }\end{array}$ & $\begin{array}{l}\text { Działanie anty- } \\
\text { utleniające }\end{array}$ & $\begin{array}{l}\text { Działanie } \\
\text { przeciwzapalne }\end{array}$ \\
\hline MPS & & + & + & & & & \\
\hline $\mathrm{CF}$ & + & & & & & & \\
\hline $\mathrm{AD}$ & & & + & + & + & + & + \\
\hline HD & & & + & + & & + & + \\
\hline PD & & & & & + & + & + \\
\hline ALS & & & & & + & + & + \\
\hline Immun. & & & & & & + & + \\
\hline
\end{tabular}

${ }^{a}$ MPS - mukopolisacharydozy; CF - mukowiscydoza; AD - choroba Alzheimera; HD - choroba Huntingtona; PD - choroba Parkinsona; ALS - stwardnienie zanikowe boczne; Immun. - choroby immunologiczne. ${ }^{b+}-$ wykazane działanie genisteiny w poszczególnych chorobach.

sowaniach medycznych. Przedstawione przykłady chorób genetycznych i immunologicznych wskazują, że profilaktyczne i lecznicze działanie tego izoflawonu często wynika ze złożonego zestawienia współdziałających mechanizmów jego działania. Na przykład, w chorobach, w których dochodzi do nieprawidłowego odkładania się różnych substancji (jak opisane tu mukopolisacharydozy, choroba Alzheimera, czy choroba Huntingtona $\mathrm{z}$ akumulowanymi odpowiednio glikozoaminoglikanami, $\beta$-amyloidem i hiperfosforylowaną formą białka tau, czy też huntingtyną) genisteina może nie tylko modulować ich metabolizm zarówno na poziomie syntezy jak i degradacji, ale również przyczyniać się do ich usuwania poprzez indukcję procesu autofagii. Dodatkowo związek ten znacznie obniża procesy zapalne będące następstwem gromadzenia się toksycznych substancji, ryzyko oksydacyjnego uszkodzenia komórek (co wynika z łatwego wchodzenia $\mathrm{w}$ reakcje $\mathrm{z}$ wolnymi rodnikami), a także liczbę komórek wchodzących na drogę apoptozy. Działania przeciwzapalne, antyoksydacyjne i antyapoptotyczne łącznie mogą również wywoływać efekt neuroprotekcyjny w chorobie Parkinsona i w stwardnieniu zanikowym bocznym, a także efekt immunoregulacyjny w chorobach autoimmunizacyjnych, alergicznych i innych przewlekłych chorobach zapalnych. Część wymienionych właściwości genisteiny wynika z jej zdolności łączenia się z receptorami estrogenów, kinazami tyrozynowymi, czy topoizomerazami, przez co wpływa ona na wytwarzanie, modulację i przekazywanie sygnałów regulujących ekspresję różnych genów. Wśród innych białek, wobec których genisteina wykazuje powinowactwo, znajduje się białko CFTR, którego funkcjonowanie zostaje przez nią poprawione w przypadku niektórych jego dysfunkcji, do jakich dochodzi w mukowiscydozie. Podsumowanie mechanizmów działania genisteiny w korygowaniu różnych procesów zachodzących w poszczególnych chorobach genetycznych i immunologicznych, co może być podstawą do terapeutycznego zastosowania tego izoflawonu, jest podsumowane $\mathrm{w}$ tabeli 1.

Chociaż wiedza na temat biologicznych aktywności genisteiny stale się powiększa i coraz precyzyjnej rozumiemy molekularne mechanizmy, które za nimi stoją, to sieć powią- zań wszystkich procesów biochemicznych, które mogą być przez nią modulowane nie została jeszcze ostatecznie scharakteryzowana. Wielokierunkowy model działania tego związku wciąż wymaga dokładnych badań w przypadku każdej choroby, w terapii której mógłby być stosowany.

\section{PIŚMIENNICTWO}

1. Tuttolomondo A (2018) Editorial: genetics and gene therapy of lysosomial storage disorders. Curr Gene Ther 18: 66-67

2. Benston S (2017) Everything in moderation, even hype: learning from vaccine controversies to strike a balance with CRISPR. J Med Ethics 43:819-823

3. Edwards T, Patel NU, Blake A, et al (2018) Insights into future therapeutics for atopic dermatitis. Expert Opin Pharmacother 19: 265-278

4. Ntontsi P, Papathanassiou E, Loukides S, et al (2018) Targeted anti-IL-13 therapies in asthma: current data and future perspectives. Expert Opin Investig Drugs 27: 179-186

5. Stephenson J, Nutma E, van der Valk P, Amor S (2018) Inflammation in CNS neurodegenerative diseases. Immunology 154: 204-219

6. Panche AN, Diwan AD, Chandra SR (2016) Flavonoids: an overview. J Nutr Sci 5:e47

7. Mukund V, Mukund D, Sharma V, et al (2017) Genistein: Its role in metabolic diseases and cancer. Crit Rev Oncol Hematol 119: 13-22

8. Rahman Mazumder MA, Hongsprabhas P (2016) Genistein as antioxidant and antibrowning agents in in vivo and in vitro: A review. Biomed Pharmacother 82: 379-392

9. Rienks J, Barbaresko J, Nöthlings U (2017) Association of isoflavone biomarkers with risk of chronic disease and mortality: a systematic review and meta-analysis of observational studies. Nutr Rev 75: 616-641

10. Smeriglio A, Calderaro A, Denaro M, et al (2017) Effects of isolated isoflavones intake on health. Curr Med Chem doi: 10.2174/092986732 4666171006143047

11. Spagnuolo C, Russo GL, Orhan IE, et al (2015) Genistein and cancer: current status, challenges, and future directions. Adv Nutr 6: 408-419

12. Russo M, Russo GL, Daglia M, et al (2016) Understanding genistein in cancer: The "good" and the "bad" effects: A review. Food Chem 196: 589-600

13. Ardito F, Di Gioia G, Pellegrino MR, Muzio LL (2018) Genistein as a potential anticancer agent against head and neck squamous cell carcinoma. Curr Top Med Chem 18: 174-181

14 Kim S-H, Kim C-W, Jeon S-Y, et al (2014) Chemopreventive and chemotherapeutic effects of genistein, a soy isoflavone, upon cancer de- 
velopment and progression in preclinical animal models. Lab Anim Res 30: 143-150

15. Negretto GW, Deon M, Burin M, et al (2014) In vitro effect of genistein on DNA damage in leukocytes from mucopolysaccharidosis IVA patients. Mol Genet Metab 111: 205-208

16. Yang Y, Fix D (2006) Genetic analysis of the anti-mutagenic effect of genistein in Escherichia coli. Mutat Res 600: 193-206

17. Wang S, Fu Y, Zhao X-H (2016) The Cooperative Effect of genistein and protein hydrolysates on the proliferation and survival of osteoblastic cells (hFOB 1.19). Molecules 21: 1489

18. Klein CB, King AA (2007) Genistein genotoxicity: critical considerations of in vitro exposure dose. Toxicol Appl Pharmacol 224: 1-11

19. Kim KH, Dodsworth C, Paras A, Burton BK (2013) High dose genistein aglycone therapy is safe in patients with mucopolysaccharidoses involving the central nervous system. Mol Genet Metab 109: 382-385

20. Das B, Tandon V, Saha N (2007) Genistein from Flemingia vestita (Fabaceae) enhances $\mathrm{NO}$ and its mediator (cGMP) production in a cestode parasite, Raillietina echinobothrida. Parasitology 134: 1457-1463

21. Toner E, Brennan GP, Wells K, et al (2008) Physiological and morphological effects of genistein against the liver fluke, Fasciola hepatica. Parasitology 135: 1189-1203

22. Naguleswaran A, Spicher M, Vonlaufen N, et al (2006) In vitro metacestodicidal activities of genistein and other isoflavones against Echinococcus multilocularis and Echinococcus granulosus. Antimicrob Agents Chemother 50: 3770-3778

23. Ganai AA, Farooqi H (2015) Bioactivity of genistein: A review of in vitro and in vivo studies. Biomed Pharmacother 76: 30-38

24. Freeze HH, Kinoshita T, Schnaar RL (2015) Genetic Disorders of Glycan Degradation. In: Varki A, Cummings RD, Esko JD, et al (eds) Essentials of Glycobiology, 3rd ed. Cold Spring Harbor Laboratory Press, Cold Spring Harbor (NY)

25. Kloska A, Tylki-Szymanska A, Wegrzyn G (2011) Mukopolisacharydozy - biochemiczne mechanizmy chorób oraz możliwości terapeutyczne. Postepy Biochem 57: 133-147

26. Urayama A, Grubb JH, Sly WS, Banks WA (2008) Mannose 6-phosphate receptor-mediated transport of sulfamidase across the bloodbrain barrier in the newborn mouse. Mol Ther 16: 1261-1266

27. Jakóbkiewicz-Banecka J, Piotrowska E, Narajczyk M, et al (2009) Genistein-mediated inhibition of glycosaminoglycan synthesis, which corrects storage in cells of patients suffering from mucopolysaccharidoses, acts by influencing an epidermal growth factor-dependent pathway. J Biomed Sci 16: 26

28. Beck M (2007) New therapeutic options for lysosomal storage disorders: enzyme replacement, small molecules and gene therapy. Hum Genet 121: 1-22

29. Piotrowska E, Jakóbkiewicz-Banecka J, Barańska S, et al (2006) Genistein-mediated inhibition of glycosaminoglycan synthesis as a basis for gene expression-targeted isoflavone therapy for mucopolysaccharidoses. Eur J Hum Genet 14: 846-852

30. Moskot M, Montefusco S, Jakóbkiewicz-Banecka J, et al (2014) The phytoestrogen genistein modulates lysosomal metabolism and transcription factor EB (TFEB) activation. J Biol Chem 289: 17054-17069

31. Moskot M, Jakóbkiewicz-Banecka J, Kloska A, et al (2015) Modulation of expression of genes involved in glycosaminoglycan metabolism and lysosome biogenesis by flavonoids. Sci Rep 5: 9378

32. Malinowska M, Wilkinson FL, Bennett W, et al (2009) Genistein reduces lysosomal storage in peripheral tissues of mucopolysaccharide IIIB mice. Mol Genet Metab 98: 235-242

33. Friso A, Tomanin R, Salvalaio M, Scarpa M (2010) Genistein reduces glycosaminoglycan levels in a mouse model of mucopolysaccharidosis type II. Br J Pharmacol 159: 1082-1091

34. Malinowska M, Wilkinson FL, Langford-Smith KJ, et al (2010) Genistein improves neuropathology and corrects behaviour in a mouse model of neurodegenerative metabolic disease. PLoS ONE 5: e14192

35. Kingma SDK, Wagemans T, IJlst L, et al (2015) Adverse Effects of Genistein in a Mucopolysaccharidosis Type I Mouse Model. JIMD Rep 23: 77-83
36. Piotrowska E, Jakóbkiewicz-Banecka J, Tylki-Szymanska A, et al (2008) Genistin-rich soy isoflavone extract in substrate reduction therapy for Sanfilippo syndrome: An open-label, pilot study in 10 pediatric patients. Curr Ther Res Clin Exp 69: 166-179

37. Piotrowska E, Jakobkiewicz-Banecka J, Maryniak A, et al (2011) Two-year follow-up of Sanfilippo Disease patients treated with a genistein-rich isoflavone extract: assessment of effects on cognitive functions and general status of patients. Med Sci Monit 17: CR196-202

38. Malinová V, Węgrzyn G, Narajczyk M (2012) The use of elevated doses of genistein-rich soy extract in the gene expression-targeted isoflavone therapy for Sanfilippo disease patients. JIMD Rep 5: 21-25

39. Nazareth D, Walshaw M (2013) Coming of age in cystic fibrosis - transition from paediatric to adult care. Clin Med (Lond) 13: 482-486

40. De Lisle RC (2009) Pass the bicarb: the importance of $\mathrm{HCO}_{3}$ - for mucin release. J Clin Invest 119: 2535-2537

41. Cohn JA, Friedman KJ, Noone PG, et al (1998) Relation between mutations of the cystic fibrosis gene and idiopathic pancreatitis. N Engl J Med 339: 653-658

42. McCallum TJ, Milunsky JM, Cunningham DL, et al (2000) Fertility in men with cystic fibrosis: an update on current surgical practices and outcomes. Chest 118: 1059-1062

43. Sheppard DN, Welsh MJ (1999) Structure and function of the CFTR chloride channel. Physiol Rev 79: S23-45

44. Wegrzyn G, Jakóbkiewicz-Banecka J, Gabig-Cimińska M, et al (2010) Genistein: a natural isoflavone with a potential for treatment of genetic diseases. Biochem Soc Trans 38: 695-701

45. Du K, Sharma M, Lukacs GL (2005) The DeltaF508 cystic fibrosis mutation impairs domain-domain interactions and arrests post-translational folding of CFTR. Nat Struct Mol Biol 12: 17-25

46. Amaral MD (2004) CFTR and chaperones: processing and degradation. J Mol Neurosci 23: 41-48

47. Weinreich F, Wood PG, Riordan JR, Nagel G (1997) Direct action of genistein on CFTR. Pflugers Arch 434: 484-491

48. Wang F, Zeltwanger S, Yang IC, et al (1998) Actions of genistein on cystic fibrosis transmembrane conductance regulator channel gating. Evidence for two binding sites with opposite effects. J Gen Physiol 111: $477-490$

49. Schmidt A, Hughes LK, Cai Z, et al (2008) Prolonged treatment of cells with genistein modulates the expression and function of the cystic fibrosis transmembrane conductance regulator. Br J Pharmacol 153: 1311-1323

50. Gadsby DC, Vergani P, Csanády L (2006) The ABC protein turned chloride channel whose failure causes cystic fibrosis. Nature 440: 477483

51. Illek B, Zhang L, Lewis NC, et al (1999) Defective function of the cystic fibrosis-causing missense mutation G551D is recovered by genistein. Am J Physiol 277: C833-839

52. Moran O, Galietta LJV, Zegarra-Moran O (2005) Binding site of activators of the cystic fibrosis transmembrane conductance regulator in the nucleotide binding domains. Cell Mol Life Sci 62: 446-460

53. Clunes MT, Boucher RC (2008) Front-runners for pharmacotherapeutic correction of the airway ion transport defect in cystic fibrosis. Curr Opin Pharmacol 8: 292-299

54. Cui L, Aleksandrov L, Chang X-B, et al (2007) Domain interdependence in the biosynthetic assembly of CFTR. J Mol Biol 365: 981-994

55. Huang J, Nasr M, Kim Y, Matthews HR (1992) Genistein inhibits protein histidine kinase. J Biol Chem 267: 15511-15515

56. Markovits J, Linassier C, Fossé P, et al (1989) Inhibitory effects of the tyrosine kinase inhibitor genistein on mammalian DNA topoisomerase II. Cancer Res 49: 5111-5117

57. Akiyama T, Ishida J, Nakagawa S, et al (1987) Genistein, a specific inhibitor of tyrosine-specific protein kinases. J Biol Chem 262: 5592-5595

58. Ye S, Cihil K, Stolz DB, et al (2010) c-Cbl facilitates endocytosis and lysosomal degradation of cystic fibrosis transmembrane conductance regulator in human airway epithelial cells. J Biol Chem 285: 2700827018 
59. Arora K, Yarlagadda S, Zhang W, et al (2016) Personalized medicine in cystic fibrosis: genistein supplementation as a treatment option for patients with a rare S1045Y-CFTR mutation. Am J Physiol Lung Cell Mol Physiol 311: L364-374

60. Andrew RJ, Kellett KAB, Thinakaran G, Hooper NM (2016) A Greek tragedy: the growing complexity of Alzheimer amyloid precursor protein proteolysis. J Biol Chem 291: 19235-19244

61. Arendt T, Stieler JT, Holzer M (2016) Tau and tauopathies. Brain Res Bull 126: 238-292

62. Naj AC, Schellenberg GD, Alzheimer's Disease Genetics Consortium (ADGC) (2017) Genomic variants, genes, and pathways of Alzheimer's disease: An overview. Am J Med Genet B Neuropsychiatr Genet 174: $5-26$

63. Chang JL, Hinrich AJ, Roman B, et al (2018) Targeting Amyloid- $\beta$ Precursor Protein, APP, Splicing with Antisense Oligonucleotides Reduces Toxic Amyloid- $\beta$ Production. Mol Ther doi: 10.1016/j. ymthe.2018.02.029

64. Youn K, Park J-H, Lee S, et al (2018) BACE1 Inhibition by genistein: Biological evaluation, kinetic analysis, and molecular docking simulation. J Med Food 21: 416-420

65. Liu C-C, Liu C-C, Kanekiyo T, et al (2013) Apolipoprotein E and Alzheimer disease: risk, mechanisms and therapy. Nat Rev Neurol 9: 106118

66. Park Y-J, Ko JW, Jeon S, Kwon YH (2016) Protective Effect of Genistein against Neuronal Degeneration in ApoE-/- Mice Fed a High-Fat Diet. Nutrients 8: 692

67. Bonet-Costa V, Herranz-Pérez V, Blanco-Gandía M, et al (2016) Clearing amyloid- $\beta$ through PPAR $\gamma /$ ApoE activation by genistein is a treatment of experimental Alzheimer's disease. J Alzheimers Dis 51: 701-711

68. Chmielewska-Kassassir M, Woźniak LA, Ogrodniczek P, Wójcik M (2013) The role of peroxisome proliferator-activated receptors $\gamma$ (PPAR $\gamma$ ) in obesity and insulin resistance. Postepy Hig Med Dosw (Online) 67: 1283-1299

69. Ye S, Wang T-T, Cai B, et al (2017) Genistein protects hippocampal neurons against injury by regulating calcium/calmodulin dependent protein kinase IV protein levels in Alzheimer's disease model rats. Neural Regen Res 12: 1479-1484

70. Wang Y, Cai B, Shao J, et al (2016) Genistein suppresses the mitochondrial apoptotic pathway in hippocampal neurons in rats with Alzheimer's disease. Neural Regen Res 11: 1153-1158

71. Gamba P, Leonarduzzi G, Tamagno E, et al (2011) Interaction between 24-hydroxycholesterol, oxidative stress, and amyloid- $\beta$ in amplifying neuronal damage in Alzheimer's disease: three partners in crime. Aging Cell 10: 403-417

72. Bagheri M, Joghataei M-T, Mohseni S, Roghani M (2011) Genistein ameliorates learning and memory deficits in amyloid $\beta(1-40)$ rat model of Alzheimer's disease. Neurobiol Learn Mem 95: 270-276

73. Zhou X, Yuan L, Zhao X, et al (2014) Genistein antagonizes inflammatory damage induced by $\beta$-amyloid peptide in microglia through TLR4 and NF-KB. Nutrition 30: 90-95

74. Li R, He P, Cui J, et al (2013) Brain endogenous estrogen levels determine responses to estrogen replacement therapy via regulation of BACE1 and NEP in female Alzheimer's transgenic mice. Mol Neurobiol 47: 857-867

75. Ross CA, Tabrizi SJ (2011) Huntington's disease: from molecular pathogenesis to clinical treatment. Lancet Neurol 10: 83-98

76. Gil JM, Rego AC (2008) Mechanisms of neurodegeneration in Huntington's disease. Eur J Neurosci 27: 2803-2820

77. Túnez I, Tasset I, Pérez-De La Cruz V, Santamaría A (2010) 3-Nitropropionic acid as a tool to study the mechanisms involved in Huntington's disease: past, present and future. Molecules 15: 878-916

78. Menze ET, Esmat A, Tadros MG, et al (2016) Genistein improves sensorimotor gating: Mechanisms related to its neuroprotective effects on the striatum. Neuropharmacology 105: 35-46
79. Pierzynowska K, Gaffke L, Hać A, et al (2018) Correction of Huntington's disease phenotype by genistein-induced autophagy in the cellular model. Neuromolecular Med 20: 112-123

80. Pierzynowska K, Gaffke L, Cyske Z, et al (2018) Autophagy stimulation as a promising approach in treatment of neurodegenerative diseases. Metab Brain Dis doi: 10.1007/s11011-018-0214-6

81. Sawada H, Shimohama S (2003) Estrogens and Parkinson disease: novel approach for neuroprotection. Endocrine 21: 77-79

82. Kaul S, Anantharam V, Yang Y, et al (2005) Tyrosine phosphorylation regulates the proteolytic activation of protein kinase Cdelta in dopaminergic neuronal cells. J Biol Chem 280: 28721-28730

83. Marsen TA, Egink G, Suckau G, Baldamus CA (1999) Tyrosine-kinase-dependent regulation of the nitric oxide synthase gene by endothelin-1 in human endothelial cells. Pflugers Arch 438: 538-544

84. Dong Z, Qi X, Xie K, Fidler IJ (1993) Protein tyrosine kinase inhibitors decrease induction of nitric oxide synthase activity in lipopolysaccharide-responsive and lipopolysaccharide-nonresponsive murine macrophages. J Immunol 151: 2717-2724

85. Gupta SP, Patel S, Yadav S, et al (2010) Involvement of nitric oxide in maneb- and paraquat-induced Parkinson's disease phenotype in mouse: is there any link with lipid peroxidation? Neurochem Res 35: 1206-1213

86. Yadav S, Gupta SP, Srivastava G, et al (2012) Role of secondary mediators in caffeine-mediated neuroprotection in maneb- and paraquat-induced Parkinson's disease phenotype in the mouse. Neurochem Res 37: $875-884$

87. Baluchnejadmojarad T, Roghani M, Nadoushan MRJ, Bagheri M (2009) Neuroprotective effect of genistein in 6-hydroxydopamine hemi-parkinsonian rat model. Phytother Res 23: 132-135

88. Bąk D, Milewski M (2005) Choroby związane z agregacją białek. Postepy Biochem 51: 297-307

89. Iłżecka J (2012) Mechanizmy patogenetyczne stwardnienia bocznego zanikowego. Aktualn Neurol 12: 222-235

90. Trieu VN, Uckun FM (1999) Genistein is neuroprotective in murine models of familial amyotrophic lateral sclerosis and stroke. Biochem Biophys Res Commun 258: 685-688

91. Trieu VN, Liu R, Liu X-P, Uckun FM (2000) A specific inhibitor of Janus kinase-3 increases survival in a transgenic mouse model of amyotrophic lateral sclerosis. Biochem Biophys Res Commun 267: 22-25

92. Spagnuolo C, Moccia S, Russo GL (2017) Anti-inflammatory effects of flavonoids in neurodegenerative disorders. Eur J Med Chem doi 10.1016/j.ejmech.2017.09.001

93. Masilamani M, Wei J, Sampson HA (2012) Regulation of the immune response by soybean isoflavones. Immunol Res 54: 95-110

94. Cooke PS, Selvaraj V, Yellayi S (2006) Genistein, estrogen receptors, and the acquired immune response. J Nutr 136: 704-708

95. Csaba G (2018) Effect of endocrine disruptor phytoestrogens on the immune system: present and future. Acta Microbiol Immunol Hung 65: $1-14$

96. Gameiro CM, Romão F, Castelo-Branco C (2010) Menopause and aging: changes in the immune system-a review. Maturitas 67: 316-320

97. Ding Q, Wang Y, Li N, et al (2016) Bidirectional Estrogen-Like Effects of Genistein on Murine Experimental Autoimmune Ovarian Disease. Int J Mol Sci 17: 1855

98. Yan G-R, Xiao C-L, He G-W, et al (2010) Global phosphoproteomic effects of natural tyrosine kinase inhibitor, genistein, on signaling pathways. Proteomics 10: 976-986

99. Dijsselbloem N, Goriely S, Albarani V, et al (2007) A critical role for p53 in the control of NF-kappaB-dependent gene expression in TLR4 -stimulated dendritic cells exposed to Genistein. J Immunol 178: 50485057

100.Liang YC, Huang YT, Tsai SH, et al (1999) Suppression of inducible cyclooxygenase and inducible nitric oxide synthase by apigenin and related flavonoids in mouse macrophages. Carcinogenesis 20: 19451952 
101. Choi C, Cho H, Park J, et al (2003) Suppressive effects of genistein on oxidative stress and NFkappaB activation in RAW 264.7 macrophages. Biosci Biotechnol Biochem 67: 1916-1922

102. Atluru D, Jackson TM, Atluru S (1991) Genistein, a selective protein tyrosine kinase inhibitor, inhibits interleukin-2 and leukotriene B4 production from human mononuclear cells. Clin Immunol Immunopathol 59: 379-387

103. Davis JN, Kucuk O, Djuric Z, Sarkar FH (2001) Soy isoflavone supplementation in healthy men prevents NF-kappa B activation by TNF-alpha in blood lymphocytes. Free Radic Biol Med 30: 1293-1302

104. Tamura S, Yoshihira K, Tokumaru M, et al (2010) Inhibitors for expression of $\mathrm{IgE}$ receptor on human mast cell from Puerariae Flos. Bioorg Med Chem Lett 20: 3872-3875

105. Tedeschi A, Lorini M, Galbiati S, et al (2000) Inhibition of basophil histamine release by tyrosine kinase and phosphatidylinositol 3-kinase inhibitors. Int J Immunopharmacol 22: 797-808

106. Lavens SE, Peachell PT, Warner JA (1992) Role of tyrosine kinases in IgE-mediated signal transduction in human lung mast cells and basophils. Am J Respir Cell Mol Biol 7: 637-644

107. Bao Z-S, Hong L, Guan Y, et al (2011) Inhibition of airway inflammation, hyperresponsiveness and remodeling by soy isoflavone in a murine model of allergic asthma. Int Immunopharmacol 11: 899-906

108. Masilamani M, Wei J, Bhatt S, et al (2011) Soybean isoflavones regulate dendritic cell function and suppress allergic sensitization to peanut. J Allergy Clin Immunol 128: 1242-1250.e1

109. Chang LM, Song Y, Li X-M, et al (2015) Dietary Elimination of Soybean Components Enhances Allergic Immune Response to Peanuts in BALB/c Mice. Int Arch Allergy Immunol 166: 304-310

110. Kalhan R, Smith LJ, Nlend MC, et al (2008) A mechanism of benefit of soy genistein in asthma: inhibition of eosinophil p38-dependent leukotriene synthesis. Clin Exp Allergy 38: 103-112

111. Hirayama F, Lee AH, Binns CW, et al (2010) Dietary intake of isoflavones and polyunsaturated fatty acids associated with lung function, breathlessness and the prevalence of chronic obstructive pulmonary disease: possible protective effect of traditional Japanese diet. Mol Nutr Food Res 54: 909-917

112.Smith LJ, Holbrook JT, Wise R, et al (2004) Dietary intake of soy genistein is associated with lung function in patients with asthma. J Asthma 41: 833-843

113. Bölcs A, Nagy M, Pordán E (1991) Questions of medical responsibility. Orv Hetil 132: 1935-1938

114.Seibel J, Molzberger AF, Hertrampf T, et al (2008) In utero and postnatal exposure to a phytoestrogen-enriched diet increases parameters of acute inflammation in a rat model of TNBS-induced colitis. Arch Toxicol 82: 941-950

115. Wang J, Zhang Q, Jin S, et al (2008) Genistein modulate immune responses in collagen-induced rheumatoid arthritis model. Maturitas 59: 405-412

116.Hong Y, Wang T, Huang C, et al (2008) Soy isoflavones supplementation alleviates disease severity in autoimmune-prone MRL-lpr/lpr mice. Lupus 17: 814-821

117. Choi MS, Jung UJ, Yeo J, et al (2008) Genistein and daidzein prevent diabetes onset by elevating insulin level and altering hepatic gluconeogenic and lipogenic enzyme activities in non-obese diabetic (NOD) mice. Diabetes Metab Res Rev 24: 74-81

118. Castro SBR, Junior COR, Alves CCS, et al (2012) Immunomodulatory effects and improved prognosis of experimental autoimmune encephalomyelitis after O-tetradecanoyl-genistein treatment. Int Immunopharmacol 12: 465-470

119.Zhang K, Wang Y, Ma W, et al (2017) Genistein improves thyroid function in Hashimoto's thyroiditis patients through regulating Th1 cytokines. Immunobiology 222: 183-187

120. Portman MA, Navarro SL, Bruce ME, Lampe JW (2016) Soy isoflavone intake is associated with risk of Kawasaki disease. Nutr Res 36 $827-834$

\title{
Molecular mechanisms of genistein action in the light of therapies for genetic and immunological diseases
}

\author{
Karolina Pierzynowska, Magdalena Podlacha, Joanna Brokowska, Lidia Gaffke, \\ Jagoda Mantej, Zuzanna Cysk, Estera Rintz, Marta Osiadły, Michał Bartkowski, \\ Michał Puchalski, Michał Grabski, Michał Pierzynowski, Dominika Pankanin, \\ Ewa Piotrowska, Stefan Tukaj, Grzegorz Węgrzyn
}

Department of Molecular Biology, Faculty of Biology, University of Gdańsk, 59 Wita Stwosza St., 80-308 Gdańsk, Poland

e-mail: grzegorz.wegrzyn@biol.ug.edu.pl

Key words: Genistein, rare diseases, genetic diseases, immunological diseases

\begin{abstract}
Genetic and immunological diseases, despite many attempts to develop effective treatments, still remain a great challenge for medicine. Current therapies of these diseases consist of pharmacological alleviation of symptoms, rehabilitation and psychological help which, although very important, are not sufficient. Therefore, searching for new therapeutics which could remove the major causes of these diseases is of particular importance for the society. Natural compounds reveal many biological activities which makes them candidates for drugs in such diseases. One of them is genistein, a compound from the group of flavonoids. As it affects multiple processes, genistein has become in the center of interest of many scientists working on diseases of various etiology, course and inheritance. It was used in experimental therapies of some genetic diseases (Huntington's disease, amyotrophic lateral sclerosis Parkinson disease, cystic fibrosis), as well as autoimmunological diseases and allergies. Clinical trials with the use of genistein in treatment of patients suffering from Alzheimer's diseases and mucopolysaccharidosis type III are ongoing. The employment of differential properties of genistein in attempts to treat each of these diseases is of special interest. In this review, detailed molecular mechanisms of genistein action are summarized in the light of therapies of the above mentioned genetic and immunological diseases, including description of therapeutic potentials of each activity of this isoflavone, efficiency of its action, and its potential use as a drug in the future.
\end{abstract}

